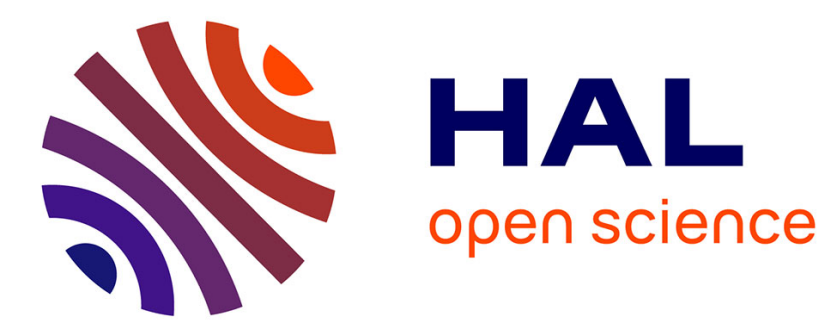

\title{
Valency and Argument Structure in the Basque Verb
}

Ricardo Rikardo, R. Etxepare

\section{To cite this version:}

Ricardo Rikardo, R. Etxepare. Valency and Argument Structure in the Basque Verb. Mouton de Gruyter, 2003. artxibo-00000087

\section{HAL Id: artxibo-00000087 https://artxiker.ccsd.cnrs.fr/artxibo-00000087}

Submitted on 15 Mar 2006

HAL is a multi-disciplinary open access archive for the deposit and dissemination of scientific research documents, whether they are published or not. The documents may come from teaching and research institutions in France or abroad, or from public or private research centers.
L'archive ouverte pluridisciplinaire HAL, est destinée au dépôt et à la diffusion de documents scientifiques de niveau recherche, publiés ou non, émanant des établissements d'enseignement et de recherche français ou étrangers, des laboratoires publics ou privés. 


\section{Valency and Argument Structure in the Basque Verb}

\section{CONTENTS}

1. Valency and the Auxiliary System. An Outline.

2. Intransitive Monovalent Structures

2.1. Existence

2.2. Copular constructions

2.3. Existential constructions

2.4. Verbs of Location and Motion

2.5. Verbs of Happening and Appearance

2.6. Verbs of Change of state

2.7. Weather Verbs

2.8. Aspectual and Control Verbs

2.9. Reflexives

3. Intransitive bivalent structures

3.1. The status of the dative

3.2. Alternating verbs

3.3. Aspectual verbs

4. Transitive Structures

4.1. Unergatives

4.2. Causative/Inchoative Alternation

4.3. Locative alternation

4.4. Transitive verbs with affected objects

4.5. Pit -verbs

4.6. Psych-Verbs

4.6.1. Lexical verbs

4.6.2. Noun + Auxiliary constructions

4.7. Complex predicates

4.7.1. Complex predicates with egin "do"

4.7.2. Other complex predicates: hartu "to take", eman "to give"

4.8. Aspectual verbs: eroan,...

5. Ditransitive Structures

5.1. Trivalent ditransitive

5.2. Bivalent ditransitive

5.3. Alternating verbs

6. Possessive Constructions

6.1. Attributive

6.1.1. Individual level attributions

6.1.2. Stage level attributions

6.2. From transitive and intransitive verbs

7. Verbs of Saying, Thinking and Judging

7.1. Intransitives

7.2. Transitives

7.3. Ditransitives 


\section{Valency and the Auxiliary System. An Outline.}

Leaving aside a small set of verbs (see 3.6.3.), Basque finite verbs are composed of an morphologically independent lexical verb carrying aspectual information, and a clitic auxiliary bearing Tense, Agreement and Modal affixes. The choice of auxiliaries in Basque seems to be largely dependent on the valency of the predicate. Intransitive, transitive, and ditransitive auxiliaries typically correspond to monovalent, bivalent and trivalent predicates. The arguments of the verb (participants in the event, such as agents, themes or patients, and beneficiaries) are mapped systematically by person and number morphology corresponding to grammatical functions such as subject, object and indirect object. Changes in the argument structure of the verb (as in the causative/inchoative alternation) are also signaled in the choice of the auxiliary . However, in some cases the correlation between valency and choice of auxiliary does not, or does not seem to obtain. The mismatch between valency and morphology is due in these cases to the contribution of an aspectual dimension (Grimshaw,90) (see section 1.3).

In order to maintain the two domains clear (lexical structure and morphology), I will refer to the valency of the verb with categories such as monovalent, bivalent or trivalent (see Hualde, section 3.6.3 in this book), and to its morphological expression with categories such as intransitive and transitive. The latter are familiar from the structural analysis of basic verbal paradigms (Hualde, in section 3.6.3.) and are based on the presence/absence of ergative morphology. When ergative morphology is present in the paradigm corresponding to a finite form, I will refer to that form as transitive. Otherwise, I will refer to that form as intransitive.

\subsection{Case and Agreement patterns}

Basque is an ergative language in both its case marking system and in its verbal morphology (with splits depending on Tense, see Hualde, section 3.6.3). That is, a language where subjects of intransitive verbs and objects of transitive ones are Casemarked and cross-referenced in the agreement elements of the verb identically and differently from subjects of transitive verbs. The Case marking of transitive subjects is called ergative, that of intransitive subjects and objects of transitives, absolutive. Table 1 shows the absolutive and ergative case endings in the three numbers (singular, plural and indefinite) $)^{1}$ :

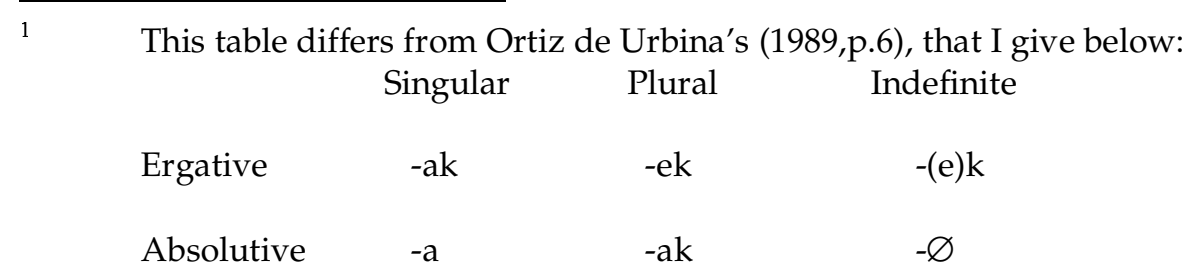

I take the common element -a- of both singular ergative and plural absolutive to be the determiner -a that one finds in all singular and plural noun phrases in Basque. Hence not part of the Case marking itself. As for the plural form of absolutives, it is probably nothing other than a combination of the 


$\begin{array}{lccc} & & \text { Table 1 } & \\ & \text { Singular } & \text { Plural } & \text { Indefinite } \\ \text { Ergative } & -\mathrm{k} & -\mathrm{ek} & -(\mathrm{e}) \mathrm{k} \\ \text { Absolutive } & \varnothing & -\varnothing & \varnothing\end{array}$

The ergative pattern is is displayed in the following examples:

(i) a. Peruk ardoa edan du

Peru-erg wine-D-abs drink Aux-T

'Peru drank wine'

b. Ardoa/Peru iritsi da

wine-D-abs/Peru-abs arrived Aux-I

'The wine/Peru arrived'

As for verbal agreement, Basque incorporates three ${ }^{2}$ types of person agreement markers: ergative, absolutive (zero in the case of third person singular), and dative.

Verbs fall into two main subclasses, according to whether they include an ergative marker (transitives) or not (intransitives). Each class will incorporate a dative marker if there is a dative argument in the clause. Auxiliaries containing an ergative marker are built up on the (auxiliary) verb *edun (to have), whereas the auxiliaries that bear no ergative marker are built up on the verb izan (to be). We have then four classes out of all logical combinations of Ergative, Absolutive and Dative:
a. Absolutiveb. Absolutive-Dative
(IZAN)
c. Ergative-absolutive
d. Ergative-Absolutive-Dative ( ${ }^{*}$ EDUN)

All those combinations correspond to actual different auxiliary forms. We give below a few examples of each type:

determiner -a- and an affix indicating plurality. One finds that same combination in cases of plural agreement with absolutive subjects an objects in predicative expressions:
a. Jonek liburu-a-k irakurr-i-a-k
ditu
Jon-erg book-D-pl read-partc-D-pl
'Jon has those books read'
Aux-T
b. Adiskide-a-k etorr-i-a-k dira friend-d-pl come-partc-D-pl Aux-I
'My friends have arrived'

Indefinite ergative subjects take a vowel -e- before the Case marker if the noun to which it attaches ends in a consonant. The fact that the Case marking of indefinites does not require -e- suggests that that affix is really a plural marker in plural ergatives, perhaps fused to the Case marker $-\mathrm{k}$. Then the $-\mathrm{a}-$ that precedes the singular ergative case marker is a singular marker, identical to the singular determiner -a .

There is also an optional agreement marker that encodes the addressee (see Hualde, section 3.6.2). As it is not part of the argument structure of the verb, I will leave it aside. 
a. Joan n-a-iz

go $1 \operatorname{sing}(\mathrm{abs})$-Present-root(be)

b. Joan n-a-tza-i-o

go 1 sing(abs)-Present-root-(pre)dative-3sing(dat)

c. Erosi d-u-t

buy-partc $\varnothing$ (3sing.abs)-Present-root-1sing(erg)

d. Erosi d-i-o-t

buy-partc $\varnothing$ (3sing.abs)-Present-(pre)dative-3sing(dat)-1sing(erg)
"I went/I have left"

"I went to him"

In non-past Tenses, the agreement pattern is also ergative: the subject-affix of intransitive auxiliaries and the object affix of transitive ones are identical, and different from the transitive subject marker. Consider as an example the first person agreement marker in the two verbal forms below:
a. Etorr-i n-a-iz "I came"
come-partc 1sing(abs)-Present-root
b. Ekarri n-a-u-zu "You brought me"
bring-partc 1sing(abs)-Present-root-2sing(erg)
c. Ekarri d-u-t "I brought it"
bring-partc Present-root-1sing(erg)

\subsection{Syntactic versus Morphological Ergativity}

Although a morphologically ergative language, Basque is syntactically a nominative-accusative language. That is, grammatical constrains that affect subjects generally in nominative-accusative languages also affect subjects of transitives and subjects of intransitives in Basque. Ortiz de Urbina (1989, ch.1) presents a number of relevant grammatical phenomena in Basque illustrating this point:

(i) Control Structures

Control phenomena are clearly accusative in Basque. The gapped argument of a control structure is always the subject of either a transitive or an intransitive verb:
a. Ez dakit [ nori e e eman] neg know-I who-Dat give
'I don't know whom to give this'
b. Joni esan dio [zer e egin]
Jon-dat say Aux-DT what do
'He/she told Jon what to do'

(5a) involves two gaps in a control structures. One gap corresponds to the transitive subject, and another one to the object. Only the subject can (and must) be interpreted as coreferent with the matrix subject ${ }^{3}$. The fact that control operates on the agentive subject

Levin (1983) provides other control structures with complements of jussive verbs such as agindu
"to order" and eskatu "to ask". Ortiz de Urbina objects to the relevance of those facts on two bases: 
in (5b) and not on the patient discards an interpretation a-la Marantz (1984) of the facts.

\section{Coordinate structures:}

A common phenomenon occurring in coordinated clauses is the deletion of material in the second conjunct under referential identity with elements of the first conjunct. This sort of deletion process is available in Basque too, but is limited to subject arguments, transitive or intransitive:

(ii) [Jonek semea eskolan utzi zuen] eta [ e klasera joan zen]

Jon-erg son-abs school-in leave Aux-T and class-to go Aux-I

'Jon left his son at school, and then he (Jon/ *his son) went to class'

To the extent that those phenomena separate intransitive and transitive subjects from transitive objects (unlike in syntactically ergative languages), we can conclude that Basque behaves as a syntactically accusative language ${ }^{4}$.

first, those complements are not obligatory control structures, since they can have overt subjects, disjoint in reference from the purported controller:

(i) [Ni-k ikusteko] agindu/eskatu du

I-erg see-N-for order/ask-partc Aux-T

'*He asked/ordered for me to see it'

Then, even syntactically ergative languages, such as Dyirbal (Dixon,1979) seem to behave "accusatively" in this sort of complement. Neither is the case in indirect wh-questions such as those in (5).

$4 \quad$ Ortiz de Urbina (1989, p.18-20) following Heath (1972), presents also the following facts as supporting the idea that Basque is syntactically accusative: Some eastern dialects of Basque assign or require a genitive case for complements of nominalized verbs. Only transitive objects can acquire such a Case. Subjects of intransitives cannot. Genitive Case therefore singles out objects from subjects, be it transitive or intransitive (see Heath, 1972):
a. Horren egiteko abiatu gara
that-g do-N-for set out Aux-I
'We set out to do that (lit. ...to do of that)'
b. *Ene etortzeko...
me-g come-N-for

Although the contrast is clear in contexts such as (i), it is also the case that those purposive adverbial clauses in Basque are control structures, as evidenced by the fact that an overt subject is impossible:

(i) $*$ [Guk/gure horren egiteko] abiatu gara we-erg/we-g that-g di-N-for set out-partc Aux-I

But if so, the impossibility of (ib) follows from the theory of control, and is irrelevant to the point. As for the purported evidence brought up by the distribution of reciprocal reflexive forms ( $p .20-21)$, it reduces to the fact that they cannot appear in subject position of either transitive or intransitive verbs:

a. Adiskideek elkar ikusi dute friends-erg each-other see-partc Aux-T 'The friends saw each other' 


\subsection{Basque as an "extended" ergative language}

Ergative languages divide into two different Case patterns. One, exemplified by Dyirbal or Samoan, marks all subjects of intransitive verbs identically, irrespective of the aspectual or agentive properties of the verb or the agentive properties of the single argument. Another one, exemplified by Basque and Georgian, among other ergative languages, marks some subjects of intransitives as objects of transitives (that is, absolutive), and some others as subjects of transitive verbs (with the ergative Case). A pattern that Dixon $(1979,1994)$ calls "extended ergative". This split case marking pattern depends apparently on the aspectual properties of the verb, particularly on whether it is telic or not (see section 4.1. for a discussion on Basque; and Lyell, 1995, p.120-123 for Georgian). In this, Basque seems to express morphologically a distinction that has been noted syntactically in other languages between unaccusative and unergative predicates (Perlmutter, 1978; Burzio, 1981). Subjects of unergative predicates take the ergative Case, subjects of unaccusative predicates take the absolutive Case. In accord with Case marking, unergative predicates take the transitive auxiliary, and unaccusative predicates the intransitive one:

(iii) a. Jonek ardoa ekarri du Jon-erg wine-abs bring-partc Aux-T

'Jon brought the wine'

b. Jonek saltatu du

Jon-erg jump-partc Aux-T

'Jon jumped'

c. Jon etorri da

'Jon came'

This is the basic outline of the relation between valency, Case and auxiliary selection. Auxiliary selection and Case marking in Basque are also conditioned by the aspectual configuration of the verb phrase. This is particularly clear in the presence of measuring or affected complements (in the sense of Tenny,1994), that enforce the presence of a transitive auxiliary (section 2 and 4.4). The expression of possessive structures also affects auxiliary selection and (concomitant) Case marking. What follows is a thorough (never exhaustive) examination of the relation between argument structure, aspectual configuration and auxiliary selection.

$$
\begin{aligned}
& \text { b. *Elkar joan ziren } \\
& \text { each other go Aux-T } \\
& \text { "*Each other went' } \\
& \text { c. "Elkarrek ikusi dituzte lagunak } \\
& \text { each other-erg see-partc Aux-T friends } \\
& \text { 'Each other saw the friends' }
\end{aligned}
$$

But $(b, c)$ also lack appropriate antecedents for the reciprocal, so their ungrammaticality could be only indirectly linked to subjecthood (via binding theory). 


\section{Intransitive Monovalent Structures}

\subsection{Existence}

The most simple intransitive monovalent structure in Basque is constituted by the verb izan "to be" as a lexical verb, in statements of existence:

Izan ala ez izan, horra auzia

to be or not to be, that's the question

Ni naiz nirez, nire borondatez (Ar. K:42)

I am by myself, by my own will

Existence can also be stated through the borrowing esistitu "to exist":

(10) Esistitzen al da horrelako izakirik?

Exists-Asp Q Aux such beings

'Could there exist any such being?'

\subsection{Copular constructions}

\subsubsection{Stage and individual level predications}

Basque makes a distinction between stage level predications (those which attribute some transitory property to the subject of predication) and individual level predications (those which attribute some standing property to the subject of predication) in the auxiliaries selected to express them. Transient properties are assigned by the verb egon "to be in a location", whereas standing properties are assigned through the verb izan "to be". The distinction is akin to the one found in Spanish between ser and estar ${ }^{5}$. Izan is also used in equative sentences.

$$
\text { Haien mende gaude gu, haien mende dago Euskara (Ib.68) }
$$

their will-in are-in a location we their will-in is-in a loc Basque

5 With some important differences, discussed in Zabala (1993). It seems that, at least in some varieties, izan can occur in all contexts in which egon can occur, but egon cannot in some cases where izan is possible. Those cases are the ones presented above as typical contexts of insertion for egon. However, there is a difference in the availability of izan vis-à-vis egon : when izan is used in contexts where egon can be used a locative complement is absolutely necessary. This is not the case for egon :

(i)
a. Xabier
al da?
b. Xabier
etxean
al da?
Xabier-Abs Q is
Xabier-Abs home-loc Q is
'Is that Xabier?'
'Is Xabier home?'

‘*Is Xabier there?'

(ii)
a. Xabier
al dago? b. Xabier etxean al dago?
Xabier-Abs Q is
Xabier-Abs home-loc Q is
'Is Xabier there?'
'Is Xabier home?'

Not all speakers seem to agree on those judgements. For Zabala (1993), both izan (when it is used in the contexts where egon can be used) and egon must be accompanied by a locative complement. See Zabala (this volume) for a detailed discussion of these facts. 
'We are under their will, Basque is under their will'

(12) Nekatuta/etxean dago

tired home-at he-is (in a location)

'He is tired/home'

(13) Gu ez garanor, guez garaezer, guez gara aberri-lorrean

we not are anybody, we not are anything, we not are country carrying

ari geran txindurri txatxar batzuk besterik ( $\mathrm{Ib} .288)$

Asp are-Rel ant miserable some but

'We are nobody, we are nothing, we are but miserable ants carrying the country'

(14) Xabier argia da

Xabier-abs intellingent is

'Xabier is intelligent'

(15) Jekill doktorea Mr. Hide zen

Jekill doctor Mr. Hide was

'Dr.Jekill was Mr.Hide'

Nouns expressing jobs can be followed by either izan or egon, with two different interpretations:

a. Xabier zerbitzari dago kafetegi horretan

Xabier-abs waiter is-in a location cafe that-in

'Xabier is working as a waiter in that cafe'

b. Xabier zerbitzari(a) da

Xabier-Abs waiter is

'Xabier is a waiter'

Whereas in (a) it is implied that Xabier is just in a temporary position (a job preceded by and probably followed by, some others), (b) implies that Xabier has this characterizing job.

\subsubsection{Physical and Mental States}

As expected, given the above characterization of the diference between izan and egon, predications involving mental and physical states occur with egon (see also section 2.7. and 4.6). The verb follows a bare stage level adjective or a participle, never a locative phrase:

a. Bero/hotz nago hot/ cold be-in a location 'I am hot/cold'

b. Haserre nago angry be-in a location 'He is angry' b. Egarril gose nago thirsty/ hungry be-in a location 'I am thirsty / hungry'

b. Gaiso dago gaur fear be-in a location today 'He is sick today'

Adjectives which follow that same pattern are ados (egon) "to be in accord, to agree", 
alde (egon) "to be in favor", kontra egon "to be against", lasai egon "to be calm", uzkur egon "to be reticent", harro egon "to be proud", kexu egon "to complain (to be in complain)", ikara egon "to be scared (to be in tremble)", beltzuri egon "to be frowning/sad", jelos egon "to be jealous", urduri egon "to be nervous", larri egon "to be in a critical condition", oker egon "to be wrong", triste egon "to be sad", ziur egon "to be sure", haurdun egon "to be pregnant", oinuts egon "to be barefoot".

Although the great majority of stage level adjectives are followed by egon, there is a subset of them that is followed by izan. They are the following: ahalke (E), lotsa izan "to be ashamed", aiher izan (E) "to be desirous", bekaitz, inbiri izan "to be envious", fio izan "to trust (to be in trust)", antsi izan (E) "to be anxious", herabe izan (E) 'to be fearful, shy", damu izan "to be regretful", haizu izan (E) "to be allowed".
a. Lotsa naiz/*nago
c. Damu naiz/*nago
shame am/am-in a loc.
'I am ashamed'
Regretful am/am-in a loc.
'I am regretful'

Of those predicates, inbiri "envy", damu "regretful", lotsa "shame" and herabe "fearful" can also be constructed with the transitive auxiliary, giving rise to a possessive construction where the mental state is the possessed term and the experiencer the subject:
a. Inbiri(a) dut envy-D Aux-T
'I have envy"
b. Lots haundia dut shame big-D Aux-T 'I have shame'

Other (individual level) adjectives that are constructed with izan are only possible in the third person. They usually take a clausal complement, or a demonstrative referring to a proposition (see Artiagoitia, this volume):
a. Neke/errez da hard/easy is
'It is hard/easy'
c. Zilegi da permitted is 'It is permitted'

\subsection{Existential sentences}

Existential sentences are constructed with the verb egon in Basque ${ }^{6}$ :
a. Badago
gizon bat atean

Aff-is-location man a at the door

'There is a man at the door'

b. Gizon bat atean dago

man a door-at is-loc

\footnotetext{
${ }^{6}$ The claim is subject to the same observation as before: in some varieties, izan can be used in existential sentences.
} 
'There is a man at the door'

'A man is at the door'

\subsection{Verbs of location and directional motion}

\subsubsection{Purely ntransitive predicates}

The following verbs of location and directional motion are necessarily followed by the intransitive auxiliary izan (22-23):
a. Etorri da
b. Joan da come Aux
'He came'
go Aux
c. Ailegatu da arrive Aux
'He went/left'
'He arrived'
d. erori da
fall Aux
'He fell'
e. Partituda (E)
depart Aux-I
f. Jaiki $d a$
'He left'
get up Aux-I
'He got up'
a. Etxean egon da at home been Aux
b. Etxean gelditu da
'He has been home' home-at stayed Aux-I
'He stayed home'
c. Ez da hor kabitzen
neg Aux-I there fit
'It does not fit there'

(23)

\subsubsection{Aspectual Structure and Transitivity Alternations with Motion and Location verbs}

It has long been noted that notions such as the internal configuration of an event (its having a specified endpoint, a process subpart, or a given length of complition) defines different aspectual classes that affect the syntactic mapping of the event participants. Motion and location verbs in Basque give rise to a transitivity alternation that involves clear aspectual notions such as the affected status of an object or the measuring out of the event denoted by the verb, in the sense of Tenny (1994). The transitive structures are produced by changing the choice of auxiliary from izan "to be" to *edun "to have".

This transitivity alternation involves motion verbs such as igo "to go up", igaro "to pass by" and jaitsi "go down, descend" and ibili "to walk", whose lexical structure specifies a path along which the movement proceeds. In these cases the transitive alternate produces an "affected" reading, where the whole surface of the movement gets "used up":

a. Mendi horretara igo naiz mountain that-to rise aux-I 'I climbed to that mountain'

(25) a. Ibai hartatik igaro dira river that-through pass aux-I 'They went through that river' b. Mendi hori igo dut mountain that climb aux-T 'I climbed that mountain'

b. Ibai hura igaro dute river that cross aux- $\mathrm{T}$ 'They crossed that river'
a. Jaitsi da
b. 200 metro jaitsi
ditu
oinutsik 
go-down Aux-I

'He went down, descended'
a. Bertatik/hiru egunes ibili naiz

$200 \mathrm{mts}$ descend Aux-T barefoot

there-through/for three days walk Aux-I

'I walked over there/for three days'

c. Harainoko bidea/hiru kilometro ibili dut/ditut

there-to-g way-D/three kilometers walk Aux-T(sing/plural)

'I walked three kilometers/the way to there'

(24a) for instance can be used in contexts such as (28), but (24b) cannot:

(28) a. Mendi horretaraigo naiz, baina ez naiz tontorreraino iritsi mountain that-to climb Aux-I but neg Aux-I top-to get

'I climbed to that mountain, but i didn't get to the top'

b. Mendi huraigo dut, \#baina ez naiz tontorreraino iritsi mountain that climb Aux-T but neg Aux-I top-to get

'I climbed that mountain, \#but I didn't get to the top'

Some of these verbs, for instance igo and jaitsi, can be bivalent, in which case the nominal complement is understood as the patient or theme of the event. The auxiliary following the verb is transitive in that case too, and the transitivity alternation involved is of the causative/inchoative type (see section 4.2. in this chapter):
a. Kaxa guziak igo ditut
Box all take up aux-T
'I took up all the boxes'
b. Kaxak jeitsi ditut
box-pl take down aux-T
'I took down the boxes'

The specified distance and the object can occur together in these cases. Agreement is with the theme argument:

a. Kaxak 200 metro igo ditut

boxes-D $200 \mathrm{mts}$ take up Aux-T

'I took up the boxes 200 meters'

b. Kaxak 200 metro jeitsi ditut boxes-D $200 \mathrm{mts}$ take down Aux-T

'I took down the boxes 200 meters'

An interesting subcase of this sort of transitivity alternation is provided by two verbs of movement: iritsi and heldu, both meaning "arrive, get somewhere" ${ }^{\prime \prime 7}$. Their transitive counterpart means "reach" in the case of iritsi, and "grab" in the case of heldu . The latter requires a ditransitive auxiliary:

\footnotetext{
${ }^{7}$ Heldu also means "to ripen, to mature". See next section.
} 
a. Iritsi da arrive Aux-I

'He/she arrived'
a. Heldu da arrive Aux-I
'He/she arrived'
b. Heldu dio grab Aux-DT
'He/she grabbed him'

b. Iritsi $d u$ reach Aux-T

'He/she reached it'

Both iritsi and heldu, meaning "arrive" contrast sharply with ailegatu , also meaning "to arrive", that cannot be converted into a transitive verb. Why should iritsi and heldu, but not ailegatu have a transitive counterpart? Consider the contrast between the two verbs when they occur inside a complement to hasi , "to begin" or bukatu "to finish", two verbs that can have an aspectual function as semiauxiliaries:
a. Kamioia Iruna iristen hasi da runner Irun-to arrive begin Aux-I
'The truck began to arrive to Irun (a village)'
b. ??Kamioia Iruna ailegatzen hasi da runner stadium-to arrive begin Aux-I
'The truck began to arrive to Irun'
a. Paketeak bukatudu iristen package-Erg finish Aux-T arrive-N-Loc
'The package finished arriving'
b. ??Paketeak bukatudu ailegatzen package-Erg finish Aux-T arrive-N-Loc 'The package finished arriving'

Whereas iritsi admits being the main predication of the complement of hasi and bukatu , ailegatu doesn't. The contrast can be accounted for under the assumption that iritsi, but not ailegatu, involves in its argument structure a path structure (that can be focused on for different subparts) for the event it denotes (Jackendoff,1983, p.161-170). Observe that the rest of the pure intransitive motion verbs are also impossible under hasi with the meaning in which subparts of a purported path are selected:
a. Londresera joaten hasi da
b. Bilbora etortzen hasi da
London-to go-Ger begin Aux-I
Bilbao-to come-Ger begin Aux-I
'He began to go to London'
'He began to come to Bilbao'

In none of the above cases does the beginning refer to the internal configuration of the coming or going event, but rather to the beginning of an habitual fact: that John comes or goes somewhere frequently.

In the case of bukatu "to finish", the complement with iritsi is interpreted in terms of a path structure. An appropriate scenario for the interpretation of (28a) could be the following: the package, which was coming from Pakistan to my homevillage in the Basque Country, was lost in the village post office but finally managed to reach my 
house The complement with ailegatu cannot be interpreted that way. ailegatu ${ }^{8}$ :

Heldu, which also enters into a transitivity alternation, goes with iritsi, and not

(36) Kamioia Iruna heltzen hasi da

Truck-abs Irun-to arrive-N-ger begin Aux-I

'The truck began to arrive to Irun'

The lexical structure of iritsi and heldu, specifying a motion through a path, allows the transitive use of those verbs.

A similar distinction affects partitu (E) and joan "depart", which can only be used intransitively, and abiatu "set off", which can be used transitively. Abiatu shows an alternation similar to the jaitsi and igaro cases (ex.25-26). Observe the contrast below:
a. Abiatu
$d a$ set off
Aux-I
b. Konpainiak proiektu berri bat abiatu du company-Erg new project-Abs set off Aux-T
c. *Konpainiak hiru langile abiatu ditu company-Erg three worker set off Aux-T

Whereas the transitive abiatu allows an object such as proiektu berri bat "a new project", it does not admit an animate object such as hiru langile "three workers". The reason is that proiektu berri bat is an affected object, one that is constructed as the event goes on. Hiru langile "three workers" however cannot be affected that way: the only interpretation the complement can give rise to is one in which it is a theme, an object set in motion by an agent. This latter alternation would be of the inchoative/causative type. But in this case, to get a causative interpretation, we need a causative affix:

Konpainiak hiru langile abiarazi ditu

company-Erg three workers set off-cause Aux-T

\footnotetext{
${ }^{8}$ If verbs such as heldu or iritsi have a path structure, with a process subpart and an endpoint, we may have a partial explanation of why in some varieties of Basque the participial intransitive form of heldu , as in (i):

(ii)

$$
\begin{aligned}
& \text { Heldu da } \\
& \text { Arrive-partc Aux-I } \\
& \text { 'It arrived' } \\
& \text { 'It is arriving now (it comes)' }
\end{aligned}
$$

Is ambiguous between a process reading and a result reading. In those varieties where (i) is possible, the verb heldu lexicalizes either the process or the result state of a path structure.
} 
'The company set off three workers"

Verbs of location can also be classified according to their ability to transitivize. Consider for instance the verb gelditu which means either "remain" or "stop" in its intransitive use. When it is used transitively, only the "stop" meaning remains. The transitive alternate means "to cause $x$ to stop". The alternation is thus of the causative/inchoative type. Egon "stay, be in a location" only takes the intransitive auxiliary:

a. Zakurra bidean gelditu da dog-the way-in stop/remain aux

'The dog stopped/remained in the way'

b. Jonek zakurra gelditu du Jon-Erg dog-the stop aux 'Jon stopped the dog'

(40) Zakurra denbora luzez egon da etzanda dog-D long time be/stay Aux-I lying

'The dog stayed lying/laid for a long time'

\subsection{Verbs of occurrence and appearance}

The availability of a transitive alternate distinguishes between two subsets among the verbs of occurrence: Gertatu "to happen, to result in" and Pasatu "to happen, to come by, to go through" on the one hand, Jazo (B) "to happen, to occur" on the other.

The two meanings of gertatu are illustrated below:

a. Ezbehar bat gertatu da accident one happen Aux-I

'An accident occurred'

(42) a. Euskal arimaren mintzabide gerta dadin (MEIG III, 118)

Basque spirit-of expression result Aux-I-Subj.

'So that it results in the expression of the basque spirit'

b. Irrigarri gertatu gara

ridiculous result-partc Aux-I

'We found ourselves in ridicule'

c. Horrelako beharrean gertatu naiz

such need result-partc Aux-I

'I found myself in such a need'

In (41), gertatu is just a verb denoting occurrence. In (42), it is clearly a resultative verb, allowing secondary predication of a result state. The different meanings of pasatu are illustrated in (43)-(44).
a. Hala pasatu da so happen Aux-I

b. Jendeanitz pasa da people many pass-by Aux 
'So it happened'

a. Ibaiean zehar /ibaitik river-in through

'I went through the river'
'A lot of people came by'

pasatu naiz

pass Aux-I

In other words, there is no transitive equivalent of gertatu "to happen" or pasatu "to happen, to come by".

Only the resultative gertatu can be transitivized (45), with the meaning of "to prepare, to arrange", and only the path structure pasatu takes a transitive auxiliary (46):
a. Afaria gertatu dugu
b. Gertatu zuten urkamendia dinner prepared Aux-T arrange Aux-T scaffold-D 'We prepared the dinner'
'The arranged the scaffold'
a. Ibaia pasatu dut river cross Aux-T
'I crossed the river'
b. Gorriak pasatu ditu
hardship pass Aux-T
'He went through/endured hardship'

This transitivity alternation thus recalls the one found in motion verbs such as igo "to climb" or jaitsi "to descend".Pasatu can also have a bivalent transitive form, in the same way that verbs such as jaitsi or igo can, taking a theme argument complement:

$$
\begin{aligned}
& \text { Kontrabandoa pasatu dute } \\
& \text { contraband-D pass-partc Aux-T } \\
& \text { 'They passed the contraband' }
\end{aligned}
$$

Jazo "to happen" cannot be transitivized, as it does not have a resultative or a bounded space reading:
a. Hori jazo da that happen Aux-I
'That happened'
c. ${ }^{*}$ Hori jazo du
that happen Aux-T

b. *Parregarri jazo gara

ridicule happen Aux-I

'(Intended) we found ourselves in ridicule'

Verbs that express occurrence as a matter of chance, such as suertatu, tokatu, fortunatu, are followed invariably by an intransitive auxiliary:

\section{Halaxe/hori suertatu/fortunatu/tokatu da oraingoan}

so/that happen-partc by chance Aux-I this time

'So it happened this time/that happened this time (by chance)"

Other verbs of appearance such as agertu "to show up, to appear (somewhere)", and azaldu "to show up, to pop up, to surface" give rise to an inchoative8causative alternation. When they are transitivized they become "to show" and "to explain, to 
expose" respectively:

(50) a. Untzi bat agertu da ostertzean ship one appear Aux-I horizon-in

'A ship appeared in the horizon'

b. Azkenaldian problemak azaldu dira lately problems pop up Aux

'Problems popped up lately'

a. Nere borondatea agertu nion

my will show Aux-DT

'I show him my willingness'

b. Teorema azaldu nion

theorem explain Aux-DT

'I explained the theorem to him'

Not all verbs of appearance can enter into such an alternation. For instance desagertu "disappear" cannot. To convert desagertu into a transitive verb we need to invoke the causative affix -erazi :

$$
\begin{aligned}
& \text { Gorpua desagertarazi dute } \\
& \text { corps disappear-Cause Aux } \\
& \text { 'they made the corps disappear' }
\end{aligned}
$$

\subsection{Verbs of change of state}

Verbs of change of state can also be divided into those that admit and those that don't admit transitivization. Consider for instance the difference between jaio "be born" and sortu "come into existence". Whereas the first only involves a result state, the second one is a complex event. Only sortu allows transitivization:
a. Irunen jaio da Irun-in born Aux-I
b. Irunen sortu
da
Irun-in come-into-existence Aux
'He is born in Irun'
'He came into existence in Irun'
a. *Jaio $d u$
born Aux-T
b.Sortu $d u$
create Aux-T
'He created it/gave it birth'

A similar distinction affects garatu "to sprout, to develop", ugaldu "to multiply, to increase in number", ondu "to ripen", on the one hand, and loratu "to bloom", lilitu "to blossom", heldu "to mature" on the other. The latter do not transitivize, the former do, with the following meanings: garatu "to develop (tr), ugaldu "to multiply (tr.), ondu "to ripen(tr.)".

Verbs which denote the transition between two successive states, such as bihurtu "to become" and or more, such as bilakatu "to develop into", can be conjugated either with the intransitive or the transitive auxiliary. With the transitive auxiliary, they mean 
"to convert $\mathrm{x}$ into $\mathrm{y}$ " and "to develop $\mathrm{x}$ into $\mathrm{y}$ ":

a. Aberats bihurtu da rich become Aux-I 'He became rich'

a. Eraikin hura zahar-etxe b. Famatua bilakatu da building that old folk's home convert Aux-T 'they converted that building into an old folk's home'

b. Aberatsentzako elkartokia bilakatu dute rich-for meeting-club develop-into Aux-T 'They developed it into a meeting-club for the rich'

The verb jarri "to put", when used intransitively, with an animate subject and following a stage level adjective or an adverb denoting a mental state, also has the meaning of "to become":

Triste/pozik jarri da sad/glad put Aux-I

'He became sad/glad'

\subsection{Weather Verbs}

The event configuration of weather verbs also allows transitivity alternations. Non-eventive predications are formed with a nominal expression and the verb egon "to be in a location":
a. Bero dago
hot is
b. Hotz dago
cold is
c. Ilun dago
dark is
'It is cold'
'It is dark'
d. Ateri dago
clear is
'It is clear'

As soon as we focus on the resultative state of a weather change, we are forced to use the transitive auxiliary, ${ }^{9,0}$ :

\footnotetext{
${ }^{9}$ For some reason it does not extend to goibel "cloudy". Its perfective form requires the intransitive auxiliary:

(i) a. Goibel dago cloudy is 'It is cloudy'

b. Goibeldu da $/{ }^{*} \mathrm{du}$ cloudy-partc Aux-I/T 'It became cloudy'

${ }^{10}$ Whereas (59a-c) can specify the object of change (the day or evening becomes hot, cold or dark), (59d) cannot. In those cases, the perfective forms become intransitive (i), unless the agent or cause of change becomes itself explicit too:

(i)
a. Eguna berotu day-D warm-partc Aux-I/T 'The day became hot'
$\mathrm{da} /{ }^{*} \mathrm{du}$
c. Eguna ilundu
$\mathrm{da} /{ }^{*} \mathrm{du}$
b. Eguna hoztu da $/{ }^{*} d u$
day-D cold Aux-I/T
'The day became cold'

d. *Zerua atertu da
} 

a. Berotu $d u$
b. Hoztu $d u$
c. Ilundu $d u$
warm-partc Aux-T
cold-partc Aux-T
dark-partc Aux-T
'It has become hot'
'It has become cold'
'It has become dark'
d. Atertu du
clear-partc Aux-T
'It has become clear'

When the weather condition involves events, such as "rain", or "snow", the transitive auxiliary is the only option. The gerundive aspectual particle ari is obligatory in this case:
a. Euria ari du rain Ger Aux-T
'It is raining'
b. Elurraari du snow Ger Aux-T
'It is snowing'
c. Izotza ari du freeze Ger Aux-T 'It is freezing'

Generic statements involving atmospheric conditions also involve the transitive auxiliary, rather than egon:

a. Herrihorietan berohaundia egiten du/?dago

day-D dark-partc Aux-I/T sky clear Aux-I
'The day darkened'

(ii)
a. Hego haizeak eguna berotu du south wind-Erg day-D warm-partc Aux-T
'The south wind warmed the day'
b. Hodeiek eguna ilundu dute clouds-Erg day-D dark-partc Aux-T 'The clouds darkened the day'

Although Basque is a pro-drop language on the three basic arguments of the verb (subject,object and indirect object) on no account should the examples in (30) be interpreted as derived from regular transitive bivalent structures such as (2) above by pro-drop on the subject. Consider the following contrast, where the empty brackets represent a purported pro-dropped argument:
a. $\left.{ }^{*}\right]_{\mathrm{i}}$ berotu $\mathrm{du}$,
baina [ $]_{i}$ ez zen berez hain haize beroa
warm-partc Aux-T, but
'*It $t_{i}$ warmed, but it $t_{i}$ wasn't such a hot air'
not was by itself such warm wind-D
b. [ $]_{\mathrm{i}}$ eguna berotu du, baina []$_{\mathrm{i}}$ ez zen hain haize beroa
day-D warm-partc Aux-T, but not was such warm wind-D
'It warmed the day, but it wasn't such a hot air'

Whereas the subject of a transitive bivalent weather predicate is referential, whether pro-dropped or not, the subject of a transitive monovalent weather predicate cannot be referred to. Pro-droped elements in Basque are referential. 
country those-in hot big do-Hab Aux-T/be-in a location

'In those countries it is very hot (as a property of those countries)'

b. Ifar poloan hotz haundia egiten du/?dago

north pole-in cold big do-Hab Aux-T/be-in a location

'In the north pole, it is very cold (as a property of the pole)'

Although the transitive forms can also be used, together with the noun+egon forms, to express punctual situations:
a. Jamaikan bero haundia dago
(oraintxe)

jamaica-in hot big be-in a location (right now)

'In Jamaica it is very hot right now'

b. Jamaikan bero haundia egiten $d u$ (oraintxe)

Jamaica-in hot big do-Hab Aux-T right now

'In Jamaica it is very hot right now'

\subsection{Aspectual and Control Verbs}

\subsubsection{Aspectual Verbs}

Basque has a seemingly purely intransitive aspectual verb ari izan, which is used to form the gerundive. This aspectual verb follows a locative nominal expressing an event, or a nominalized clause ${ }^{11}$ (see Oihartzabal, this volume):
a. Lanean ari da
b. Lanean aritu da
work-in ari Aux-I
'He is writing'
work-in ari-Partc Aux-I
'He has been working'

With the same function western Basque also has egon "be in a location":
a. Lanean dago
work-in is
'He is working'
b. Lanean egon da work-in be Aux-I
'He has been working'

The verb hasi has also an aspectual, monovalent use ("to begin to"), when followed by a locative phrase containing a bare nominal or a nominalized clause. In this case it is followed by the intransitive auxiliary izan (see Artiagoitia, chapter XXX):
a. Lanean hasi naiz work-in begin Aux-I
b. Idazten hasi naiz writing begin Aux-I

\footnotetext{
${ }^{11}$ This aspectual verb is followed by a transitive auxiliary only when it follows a nominal expressing an eventive weather condition:
}

(i) Euria ari du

rain ari Aux-T

'It is raining' 
Hasi "to begin" can also be a bivalent verb, in which case it is followed by a transitive auxiliary:

(66) Nobela berribat hasi du

novel new one begin Aux-T

'He began a new novel'

Also intransitive is the verb ibili "to walk" when it is used as a frequentative aspectual auxiliary:

(67) Bere burutazioak idazten ibiltzen da

my memories writing walking Aux-I

'He is/keeps writing his thoughts'

The verb joan "to go" can be used as an aspectual verb denoting gradual change. In that case, it is preceded by a nominalized clause followed by the locative postposition:

Ohitzen joanda
Custom-N-Loc go Aux-I
'He has got used to it gradually'

\subsubsection{Control verbs: the try -class}

Control verbs of the try -class, are only conjugated with the intransitive auxiliary izan (qua control verbs). The nominalized complements of these verbs are followed by a locative suffix (see Artiagoitia, Subordination, 1.2.2.2.6) Consider for instance saiatu and ahalegindu "to try, to attempt" and ausartu "dare":

(69) Xabier irrifarre egiten saiatu/ahalegindu da

Xabier smile do-N-loc try Aux-I

'Xabier tried to smile'

Saiatu can be used also as a transitive verb only with a nominal, non-clausal complement as "to try (something)":

(70) Mirenek soineko berria saiatu du

Miren-Erg dress new try Aux-T

'Miren tried a new dress'

Neither ahalegindu nor ausartu have transitive counterparts.

\subsection{Reflexives}

In Basque, reflexivization operates either with the addition of reflexive arguments (elkar "each other" and X-ren burua "X-self" (literally "X's head")) or by 
detransitivizing the auxiliary, which becomes the intransitive izan "to be":

a. Jonek bere burua ispiluan ikusidu

Jone-Erg his head in the mirror see Aux-T

'Jon saw himself in the mirror'

b. Jon ispiluan ikusi da

jon mirror-in see Aux-I

'Jon saw himself in the mirror'

The alternation is not entirely free, however. Many arguments can only take the reflexive argument, and cannot reflexivize via detransitivization, whereas other predicates can only form their reflexive by ditransitivizing. Still, a third class of predicates can be reflexivized in either of the two ways.

A sample of verbs that do not reflexivize with the intransitive auxiliary would consist of: maite izan "to love", atsegin izan "to like", erakutsi "to exhibit", errepresentatu "to represent", irudikatu "to represent, to picture", ito "to drawn, to asfixiate", erre "to burn", jantzi "to educate" (Abs), adoretu "to encourage", akatu "to kill", miretsi, ederretsi "to admire", ezagutu "to know", hobetsi "to favor", iraunarazi "to perpetuate, to preserve", nabarmendu "to show off", nahastu "to mess up", puztu "to boast", zuritu "to justify". These verbs divide into three classes: those verbs whose intransitive forms are inchoatives, such as erre, ito , puztu, zuritu, puztu, nabarmendu, nahastu ; verbs which are stative, such as maite izan, atsegin izan, ezagutu, miretsi, ederretsi and hobetsi , and then a handful of eventive verbs involving (active) representation, such as errepresentatu, irudikatu, and erakutsi .

Those predicates whose reflexive argument is mapped into a grammatical function which is not marked Absolutive, obligatorily take a reflexive noun phrase (case or postposition of the non-absolutive argument in parentheses): burlatu "to make fun of" (Instr.), leporatu "to impute" (Dat), egotzi "to attribute" (Dat), galdetu "to ask" (Dat), fidatu "to trust" (Instr.), solastatu "to talk with" (Com.), ahaztu "to forget" (Instr), arduratu "to take responsibility for" (Instr), axolagabetu "to become unconcerned" (Instr), etsaitu "to become enemies" (Com), etsitu "to desperate" (Instr), jaramon egin "to pay attention" (Dat), kexu izan "to be uneasy with" (Instr), kasu egin "to pay attention" (Dat) sinetsi "to believe in"(loc):

a. Bere buruarengan sinesten $d u$

his head-in believe Aux-T
'He believes in himself'

b. Bere buruari galdetu dio his head-Dat ask Aux-DT 'He asked himself/wondered' b. * Sinisten $d a$ believe Aux-I

'He believes in himself'

d. *Galdetu da

ask Aux-T

'He asked himself/wondered'

Predicates that reflexivize by either a reflexive argument or by an intransitive auxiliary constitute the richest group. Among them: aurkeztu "to introduce", bota "to 
throw (e.g. oneself under the bridge)", estimatu "to appreciate", laudatu, goraipatu "to praise", gobernatu "to look after oneself", libratu "to set free", armatu "to arm", babestu "to protect", behartu "to force", defendatu "to defend", desondratu "to dishonor", engainatu "to deceive", gaitu "to able", gertatu, prestatu "to prepare, to arrange", ikusi "to see", juzkatu "to judge", konparatu "to compare", saldu "to sell (e.g. to the enemy)" zaindu "to take care of":

\section{a. Xabier etengabe goraipatu da}

Xabier-Abs continuously praise Aux-I

'Xabier has praised himself continuously'

b. Xabierrek etengabe bere burua goraipatu du

Xabier-Erg continuously his head praise Aux-T

'Xabier has praised himself continuously'

The two alternative forms are not always equivalent. This is particularly clear with constructions that specify a path structure. Take for instance a verb like babestu "to protect", that can be reflexivized through detransitivization or by a reflexive noun phrase:
a. Babestu gara protect-partc Aux-I
b. Gure buruak babestu ditugu our heads-abs protect-partc Aux-T
'We protected ourselves' 'We protected ourselves'

If we introduce an adlative modifier and create a path structure, detransitivization becomes the only available strategy:

a. Gerrilariak basora babestu dira partisans-abs wood-to protect-partc Aux-I

'The partisans protected themselves into the woods'

b. *Gerrilariak beren buruak basora babestu dituzte partisans their heads-abs woods-to protect-partc Aux-T 'The partisans protected themselves inmto the woods'

The reflexive noun phrase is again possible if the modifier is locative, and expresses the place where the partisans protect themselves:

a.Gerrilariek basoan babestu dituzte beren buruak partisans-erg wood-in protect-partc Aux-T their heads-abs 'The partisans protected themselves in the wood'

Consider now the verb bota "to throw", a verb that inherently specifies direction of motion. The alternate with the reflexive phrase gives rise to ambiguous interpretation of modifiers in a way that the intransitive altyernates don't:

a. Xabier zubiazpian bota da 
Xabier-abs under the bridge-loc throw Aux-I

'Xabier threw himself under the bridge'

b. Xabierrek bereburua zubiazpian bota du

Xabier-erg his head-abs under the bridge-loc Aux-T

'Xabier threw himself under the bridge'

In $(77 \mathrm{~b})$ the locative modifier "under the bridge" is ambiguous between two readings: one that modifies the beginning of the event (that is the place from which the jumping takes place) or the endpoint of the event (the place where the jump ends). Xabier may have thrown himself from under the bridge or to under the bridge. In (77a) no such ambiguity arises: zubiazpian "under the bridge" only localizes the place from which the jumping tales place. The ambiguity in $(77 \mathrm{~b})$ disappears if the postposition is directional. In this case the modifier marks the place from where the jumping occurred:
Xabierrek bere burua zubiazpira
bota $d u$
Xabier-erg his head-abs under the bridge-to throw Aux-T
'Xabier threw himself (to) under the bridge'

The ambiguity in the scope of the locative suggests that reflexive forms constructed with a noun-phrase reflexive have a more complex structure than the intransitive reflexive forms.

Predicates that only admit the intransitive reflexive form are the so-called inherent reflexives: gorde "to hide" jantzi "to dress", apaindu "to make up", garbitu "to wash", zikindu "to soil", idortu, lehortu "to dry". Intransitive forms here not allways have a reflexive meaning, they can also have an inchoative meaning:
a. Jantziak lehortu dira clothes dry
Aux-I
'The clothes dried'
b. Eguzkia gorde da
sun hide Aux-I
'The sun hid'
b. Lehioak zikindu dira windows soil Aux-I
'The windows soiled'
c. Zelaia lorez jantzi da
field flower-instr dress Aux-I
'The field became dressed with flowers'

All of them have also transitive forms in which the arguments are not coindexed. and which are associated to the inchoatives:

a. Xabierrek zakurra garbitu $d u$

Xabier-erg dog-Abs wash Aux-T

'Xabier washed the dog'

b. Xabier garbituda

Xabier-abs wash Aux-I

'Xabier washed'

However, none of them can take a reflexive NP: 
(81) a. Mirenek panpinajantzidu

Miren-erg doll dress Aux-T

'Miren dressed her doll'

b. *Mirenek bere burua jantzi du

Miren-erg his head dress Aux-T

'Miren dressed up'

(82) ??Mirenek bere burua garbitu du

Miren-erg his head wash Aux-T

'Miren washed'

(83) a. Mirenek ilea idortu du

Miren-erg hair dry Aux-T

'Miren dried up her hair'

b. *Mirenek bereburua idortu $d u$

Miren-erg his head dry Aux-T

'Miren dried herself up'

\section{Intransitive Bivalent Structures (dative-absolutive constructions)}

Dative-absolutive auxiliaries can be found following four different verb classes:

(i) motion verbs; (ii) psych verbs of the piacere class; (iii) "dative of interest" constructions; and finally, a small set of verbs that alternate between dative-absolutive auxiliaries and ditransitive auxiliaries. Psych verbs are extensively discussed in section 4.6. "Dative of interest" constructions are treated in section 6, as possessive constructions. Here I will deal briefly with the first and last subclasses.

\subsection{Motion verbs}

Purely intransitive motion verbs may incorporate a dative agreement marker, as the verb joan "to go" below:
a. Joan da
b. Joan zaio
go Aux-I(abs)
go Aux-I(abs-dat)
'He went'
'He went to him'

In verbs of motion, the dative argument has the role of endpoint of the motion. Consider for instance the aspectual difference between (a) and (b) above:
a. Xabier ordubietan Jonengana joan da.
Lauretarako
Xabier-abs two o' clock-at Jon-to go Aux-I(abs-dat) four-by
iritsi gabea zen (oraindik)
arrived without-Det was yet
'Xabier went to Miren at two o'clock. By four o'clock he wasn't yet there'
b. Xabier Mireni ordubietan joanzaio. \#Lauretarako iritsi
Xabier-abs Miren-dat two o'clock go Aux-I(abs-dat) four o'clock-by arrive gabea zen
without-Det was
'Xabier went to Miren at two o'clock. By four o'clock he wasn't yet there' 
Alternatively, the dative can just express a relation of possession or interest between the absolutive subject and the argument marked by dative Case (section 6). In those cases, the dative constructions can be paraphrased by a phrase internal possessive. No aspectual effect arises in these cases:

a. Jonen adiskide bat joan da

Jon-g friend one-abs leave Aux-I

'A friend of Jon left'

b. Joni adiskide bat joan zaio

Jon-dat friend one leave Aux(dat-abs)

'A friend of Jon left'

\subsection{Alternating verbs}

A few verbs show two auxiliary choices: baliatu "to be profitable for someone" and atxeki "to attach to, to stick", for instance, take either an ergative-absolutive auxiliary or a dative-absolutive one:

a. Hori baliatu zaio

that-abs profit-partc Aux(dat-abs)

'That was profitable to him'

b. Hori baliatu du that-abs profit-partc Aux-T

'He made that profitable'
a. Atxiki zaio
stick-partc Aux(dat-abs)
'It sticked to him'
b. Atxiki du stick-partc Aux-T
'He retained $\mathrm{it}^{\prime}$

When in the ergative/absolutive pattern those verbs mean, respectively, "to make something profitable" and "to retain". Only the former gives rise to a causative meaning in its transitive variant. One noun+auxiliary construction that is not a mental state also shows the same kind of alternation as (88): eskas ,falta +auxiliary "to lack" (89).
a. Zopak gatza falta du soup-erg salt-abs lack Aux-T
'The soup needs salt'
b. Zopari gatza faltazaio Soup-dat salt-abs lack Aux(dat-abs) 'The soup lacks salt'

A handful of verbs such as jarraitu "to follow" and jazarri "to rebel" use both the dative-absolutive and the ditransitive auxiliaries interchangeably. The historical record shows that those verbs were originally employed only with the dativeabsolutive auxiliary. The ditransitive auxiliary has imposed in the last couple of centuries. Jariatu "to spill" admits indistinctly both the dative-absolutive and the transitive (ergative-absolutive) auxiliaries. In its synthetic form, the dative-absolutive is the most common, although some varieties admit transitive bipersonal forms: 
(90) a. Zauriari odoladario wound-dat blood spill(dat-abs)

'The wound bleeds'

b. Etxeetako tximiniak kea dariote (Lz,BB,156)

houses-g chimney-erg smoke spill(erg-abs)

'The chimneys of the houses send up smoke'

Some noun+auxiliary constructions take the dative-absolutive auxiliary among a wider range of choices. For instance balio +auxiliary "to be worth" and axola +auxiliary "to matter":
a. Balio du
b. Balio zaio value Aux-T
value $\operatorname{Aux}($ dat-abs)
c. Balio dio value Aux-DT
'It is worth' 'It is worth/useful for him' 'It is worth/useful for him'

\subsection{An aspectual verb: lotu}

The verb lotu, which has a transitive use as "to tie" has an aspectual use in its dative-absolutive form as "to engage in":
a. Lokarriaklotu ditu ties-abs tie-partc Aux-T
b. Lanari lotu zaio work-dat tie-partc Aux(dat-abs) 'He tied his laces' 'He tied himself to work (he engaged in working)'

\section{Transitive Structures}

\subsection{Unergatives}

A class of predicates in Basque takes the transitive auxiliary but typically prohibits, or severely constrains, the availability of an overt object. This class corresponds roughly to the class of unergative predicates of other languages (Perlmutter, 78;Burzio,1981, Levin,1983). Unergative predicates have an ergative subject, typical of transitive structures. Compare in this regard a standard transitive verb such as erosi "to buy", and an unergative verb such distiratu "to shine":

a. Jonek etxe berria erosi $d u$ Jon-erg house new-D-abs buy-partc Aux-T 'Jon bought a new house'

b. Lehioko kristalak distiratu $d u$ window-of glass-erg shine-partc Aux-T

'The glass in the window shone'

c. ${ }^{*}$ Kristalak lurra distiratu $d u$ glass-erg floor shine-partc Aux-T

‘*The glass shone the floor (made the floor shine)'

Verbs of this sort are also dirdiratu "to glimmer", botatu (W) "to bounce", bozkatu "to vote", eskiatu "to sky", nabigatu "to navigate", txitatu (W) "to set on eggs", gogoetatu "to meditate", eutsi "to withstand", irakin "to boil", iraun "to persist", bazkaldu "to 
lunch", afaldu "to have dinner", usaitu "to smell".

When unergative verbs admit objects, they are either cognate objects (94), or in the case of motion verbs, complements indicating length (95):

a. Gene Kelly-k dantza famatu bat dantzatzen du film horretan

Gene Kelly-erg dance famous one dance-ger Aux-T film that-loc

'Gene Kelly dances a famous dance in that film'

b. Jolas polit bat jolastu zuten

play nice one play-partc Aux-T

'They played a nice play'

c. Abraracourcix-ek borroka luze bat borrokatzen du istorio horretan

Abraracourcix-erg fight long one fight-ger Aux-T story that-loc

'Abraracourcix fights a long fight in that story'
a. Jauzilari kubarrak bi metro saltatu ditu jumper cuban-erg two meters jump-partc aux-T(pl)
'The cuban athlete jumped two meters'
b. Bi kilometro korritu ditut oinutsik
two kilometers run-partc Aux-T barefoot

Alternatively (and most commonly), unergative verbs in Basque are complex predicates, composed by a (typically) bare noun that specifies the kind of event involved, and a verb indicating action: egin "to do" (see section 4.6). Many unergative verbs can occur in either of those two forms (96). The possibility of having a cognate object disappears in the complex predicate alternate (Uribe-Etxebarria, 1989)(97):
a. Jonek korritu $d u$
b. Jonek korri egin du
Jon-erg run-partc Aux-T
'Jon ran'
Jon-erg run do Aux-T
'Jon ran'

a. Jonek dantzabat dantzatu du

Jon-erg dance one dance-partc Aux-T

'Jon danced a dance'

b. *Jonek dantza bat dantza egin $d u$

Jon-erg dance one dance do Aux-T

'Jon danced a dance'

The existence of complex predicates of the sort above has been adduced as evidence that unergative verbs are syntactically transitive, having a thematic object in their underlying representation (Hale\&Keyser,91,93). The existence of such a correlation between syntactically transitive compound predicates and morphologically transitive simplex verbs, together with the case marking of the subject in simplex unergative predicates supports that idea. However, that correlation does not always hold: to some complex predicates formed with a bare noun or locative phrase (see section 4.6) and the verb egin "to do" correspond simplex verbs with intransitive auxiliaries and absolutive surface subjects. Among those are: hegatu "to fly" $(<h e g a n / z$ 
egin "wing-loc/instr do"), dardaratu "to tremble" (<dardar egin "trembling do"), irristatu "to slip" (<irrist egin "slip do"), behaztopatu "to stumble" (<behaztopa egin "stumble do"), solastu "to chat" (<solas(ean) egin "chat-(loc) do") and zintzatu "to sneeze" (< zintz egin "to do sneeze"). Consider as an illustration (98):

a. Jonek solas(ean) egin du gurekin

Jon-erg chat-loc do Aux-T us-with 'Jon chatted with us'

b. Jon gurekin solastu da

Jon-abs us-with chat-partc Aux-I

'Jon chatted with us'

c. *Jonek gurekin solastu du Jon-erg us-with chat-partc Aux-T 'Jon chatted with us'

Other unergative verbs optionally admit an intransitive variant. These are: jolastu "to play", borrokatu "to fight", gudukatu "to war", saltatu "to jump", dantzatu "to dance", barautu "to fasten". An example is given in (99):

a. Jonek Urtainen kontra borrokatu du Jon-erg Urtain-g against fight-partc Aux-T 'Jon fought against Urtain'

b. Jon Urtainen kontra borrokatu da Jon-abs Urtain-g against fight-partc Aux-T 'Jon fought against Urtain'

All those verbs have also transitive structures with an overt object, where the object measures the length of the event (with jolastu, saltatu, dantzatu, barautu ), as in (100), or the target of the event (with borrokatu and gudukatu), as in (101):

(100) a. Jonek bi dantza dantzatu ditu

Jon-erg two dance-abs dance-partc Aux-T

'Jon danced two dances'

b. Berrogei egun eta berrogeigau barautu zituen forty day and forty night fasten-partc Aux-T 'He fastened for forty days and forty nights'

(101) a. Urtain borrokatudu Jonek Urtain-abs fight-partc Aux-T Jon-erg

'Jon fought Urtain'

b. Gu baino sendoagorik ezdugu ba gudukatuko us than stronger-part neg aux-T then war-partc-fut

'We want war those who are stronger that us, then'

For some authors (Grimshaw,90; Pustejovsky, 92,95), the class of unergative predicates must be associated to a given aspectual configuration. Unergative predicates would be aspectual processes (Vendler,1967; Dowty 1979, Verkuyl,93 and references therein): verbs denoting an activity of indefinite length. For Grimshaw, the partial analogy between process denoting unergatives and prototypical transitive 
accomplishments is derived from the fact that they share a process subpart. Accomplishments are complex events involving both a process subpart, that counts as the event bringing about a state, and a state subpart, denoting the result of the causation process. Agents and causes are typically related to the process subpart of a complex event, and they are mapped as the most prominent grammatical function: as (non-derived) subjects. If unergatives are processes, their single argument will be mapped as a non-derived, ergative subject too. Although such a proposal would explain the fact that all unergative verbs which are morphologically transitive are actually aspectual processes (see the list above), it fails to account for the fact that some of them either are, or can optionally be, intransitive. At least under the assumption that ergative Case should be invariably linked to non-derived subjects. It is also worth noting that the set of complex predicates, according to this characterization of unergative predicates, is actually larger than the set of aspectual processes. Complex predicates such as behaztopa egin "to stumble", irrist/laban egin "to slip" or zintz egin "to sneeze" are not aspectual processes. Interestingly, all those have intransitive simple couterparts.

Levin\&Rappaport (1995) propose to derive the class of unergative verbs from the notion of "internally caused event". In internally caused eventualities, some property inherent to the argument of the verb is "responsible" for bringing about the eventuality. This is inmediately clear in the case of verbs such as korritu "to run" or bozkatu "to vote", that depend on the volition or will of the agent who performs that activity. Levin \&Rappaport extend it also to verbs such as distiratu "to shine" or irakin "to boil" which are not agentive. Those verbs can be taken to describe internally caused eventualities because those eventualities arise from internal properties (material structure) of the arguments. In Basque, the correlation between internally caused event and transitive auxiliary is not clear-cut. Events which are externally or internally caused (in the sense of Levin and Rappaport) require the intransitive auxiliary (dardaratu "to tremble", hegatu, hegaldatu "to fly", solastu "to chat", zintzatu "to sneeze") whereas others optionally take it: jolastu "to play", borrokatu "to fight", gudukatu "to war", dantzatu "to dance". Although those verbs either do not take or do not necessarily take the transitive auxiliary, a diagnostic for unergativity in Basque, they do not allow (lexical) causative variants either ${ }^{12}$, as other standard intransitive verbs do. This is a standard test for unergativity (Hale\&Keyser, 1993, and references therein):
a. *Berriak Mikel dardaratu du news-erg Mikel-abs tremble-partc Aux-T
'*The news trembled Mikel (made Mikel tremble)'
b. *Ehiztariak aztorea hegatu $d u$

\footnotetext{
${ }^{12}$ To derive their causatives we need an extra causative affix: -erazi. As an illustration:
}

\author{
Berriak Mikel dardara-erazi du \\ News-erg Mikel-abs tremble-cause Aux-T \\ 'The news made Mikel tremble'
}


hunter-erg hawk-abs fly-partc Aux-T

'*The hunter flew the hawk (made the hawk fly)'

c. *Pailazoakhaurrak jolastu ditu

clown-erg children-abs play-partc Aux-T

'The clown played the children (made the children play)'

\subsection{Causative/Inchoative Alternation}

This transitivity alternation affects typically those change of state verbs that are constructed out of adjectives such as garbi "clean", ilun "obscure", argi "clear", zikin "dirty" or arin "light". The alternation can be transparently described by adding a causative layer to the intransitive counterpart. For instance garbitu "to clean":
a. Garbitu da clean-partc Aux-I
b. Garbitu du
'It became clean'
clear-partc Aux-T
'Someone cleaned it (made it become clean)'

Other verbs not derived from adjectives can also produce this alternation. For instance, verbs of directed motion:
a. Xabier sartu da Xabier enter Aux-I
b. Xabierrek kotxea sartudu Xabier-Erg car-Abs enter aux-T Xabier get out Aux-I
a. Xabier atera da
b. Xabierrek kotxea atera $d u$ Xabier-Erg car-Abs take out Aux-T

Also all those verbs constructed from a noun specifying the endpoint of a motion and an adlative suffix that encodes direction: home-to-partc Aux-I 'He went home'
a. Etxe-ra-tu da
a. Oheratu da
bed-to-partc Aux-I
'He went to bed'
b. Norbait etxe-ra-tu du someone home-to-partc Aux-T 'He took someone home'
b. Norbait oheratu $d u$ someone bed-to-partc Aux-T 'He put someone to bed'

\subsection{Monovalent transitive structures with measuring objects}

A few transitive verbs admit monovalent structures in which the object measures out the event. Some of them require a locative or a comitative phrase that denotes an activity. The verbs in question are eman "to give", egin "to do", and bete "to fill".
(108)
a. Dirua eman $d u$ money give Aux-T 'He/she gave money'
a. Zerbait egin $d u$ something do Aux-T 'He/she did something'
a. Botila bete du

b. Urteak eman ditu horretan years-abs give Aux-T that-in 'He/she spent years on that'

b. Egunak egin ditu horrekin days-abs do Aux-T that-with 'He spent days with that'

b. Zigorra bete du 
bottle-abs fill Aux-T

'He filled the bottle' (prison) term-abs accomplish Aux-T

'He accomplished his prison term'

\subsection{Locative alternation}

A few transitive verbs give rise to a locative alternation of the spray-load type (from Rebuschi, 82, p.347):
a. Patxik soroan garia
erein $d u$

Patxi-erg field-in wheat-abs sow Aux-T

'Patxi sowed wheat in the field'

b. Patxik soroa gariz erein $d u$

Patxi-erg field-abs wheat-instr sow Aux-T

'Patxi sowed the field with wheat'

a. Patxik sagarrak kamioian kargatu ditu

Patxi-erg apples-abs truck-in load Aux-T(pl.abs)

'Patxi loaded the apples in the truck

b. Patxik kamioia sagarrez kargatuzuen

Patxi-erg truck-abs apple-instr load Aux-T(sing.abs)

'Patxi loaded the truck with apples'

\subsection{Pit -verbs}

A small class of verbs of change of state, all of them related to growing, gives rise to a puzzling alternation. In this alternation, the transitive counterpart is interpreted as expressing a removal of the thing growed. Consider for instance the following unaccusative verbs:
a. Artaburuak aletu dira corn-ears-abs pit-partc Aux-I 'The corn (ears of) grew pits'
b. Adarrak kimatu dira
Branches-abs bud-partc Aux-I
'The branches budded'
c. Txitak lumatu dira chicks-abs grew-feathers-partc Aux-I 'The chicks grew feathers'
a. Artaburuakaletu dituzte corn-abs pit-partc Aux-T 'They pitted the corn'
c. Txitak lumatu dituzte chicks-abs pluck-partc Aux-T 'They plucked the chicks'
b. Adarrak kimatu dituzte branches-abs trim-partc Aux-T 'They trimmed the branches'

Not all verbs of growing give rise to this alternation: lilitu "to flower" , loratu "to bloom", abartu "to grow branches", hostatu , orritu "to sprout leaves" do not admit it, although all of them have zero-related nominals (abar "branch", hosto , orri "leave"). A 
relation of inalienable possession or part-whole underlies this alternation (see Levin, 1993, p.130, for the same alternation in English). But that condition alone doesn't seem to exclude inexistent potential cases such as *abartu "to remove branches", or *hostatu "to remove leaves".

\subsection{Complex predicates}

\subsubsection{Complex predicates with egin}

\subsubsection{Basic pattern}

Basque has a very productive way of creating new predicates out of the combination of the verb egin "to do" and a bare nominal indicating the kind of action entertained. These complex predicates are typically equivalent to unergative predicates of other languages (Levin,1983; Ortiz de Urbina,1989; Uribe-Etxebarria,1989; Laka,1993). The result is a syntactically transitive construction, whose subject is marked Ergative:
a. Jonek lan egiten $d u$ Jon-Erg work do-Gen Aux-T 'Jon works'
b. Mikelek salto egin du
Mikel-Erg jump do Aux-T
'Mikel jumped'

Here is sample of predicates formed in this way:

A. Verbs of emission:

\section{a.1. Verbs of sound emission:}

Auhen egin "to lament (to do lament)" ,deiadar egin "to scream (to do scream) , intziri egin "to moan (to do moan)", uhuri/ulu egin "to howl (to do howl)", hasperen egin "to sigh (to do sigh)", oihu egin "to yell (to do yell)", negar egin "to cry (to do cry)", orro egin "to roar (to do roar)", marrixka egin "to meow (to do meow)", irri egin "to laugh (to do laugh)", kirrinka egin "to creak (to do creak)".

\section{a.2. Light emission:}

Dir-dir egin "to shine", diz-diz egin "to glow, to sparkle", nir-nir egin "to twinker, flicker".

\section{a.3. Verbal emission:}

Birao egin "to blaspheme (to do blaspheme)", burla egin "to make fun", errieta egin , agiraka egin "to reprehend" , oles egin "to summon", marmar egin "to grunt" , dei egin, hots egin "to call", zin egin "to swear".

B. Internal body motion:

Dar-dar egin "to tremble (to do tremble)", bor-bor egin "to boil noisily (to do boiling noise)". 


\section{Physical activities}

c.1. Actions against an object or an individual:

Ausiki egin "to bite (to do bite)", tiro egin "to shoot (to do shoot)", bultza egin "to push (to do push)", saka egin "to press, to push, to shove (to do press, etc)", indar egin "to make an effort", gogor egin "to struggle (to do force)" , buru egin "to face, to hold (to do head)", zizt egin "to puncture (to do puncture)", laztan egin "to caresse (to do caress)" , putz egin "to blow (to do blow)", iskin egin "to elude (to do corner)".

\section{c.2. Motion verbs:}

Laster/korri egin "to run (to do run)", ihes egin "to flee (to do flee)", salto egin "to jump (to do jump)" , igeri egin "to swim (to do swim)", hanka egin "to escape rapidly (to do leg)", alde egin "to leave (to do distance)" , zirkin egin "to move (to do move)".

\section{c.3. Bodily functions:}

Aharrausi egin "to yawn (to do yawn)", kaka egin "to shit (to do shit)", txiza egin "to urinate (to do urine)", zintz egin "to blow one's nose", izerdi egin "to sweat "to do sweat", usin egin "to sneeze (to do sneeze)", arnas egin "to breath "to do breath", hatz egin "to scratch (to do finger)", lo egin "to sleep (to do sleep)".

\section{Mental activities}

Duda egin "to doubt (to do doubt)" , gogoeta egin "to meditate (to do meditation)", hausnar egin "to ruminate (fig.) (to do rumination)", kasu egin "to pay attention (to do attention)", kontu egin "to take into account (to do count)", hitz/berba egin "to talk (to do talk)", otoitz egin "to pray (to do pray)", amets egin "to dream (to do dream)", solas egin "to chat (to do chat)".

E. Behavioral verbs:

Axut/desafio egin "to challenge (to do challenge)", mehatxu egin "to threaten (to do threaten)", planto egin "to stop by refusing to follow a game (to do stop)", paso egin (W) "to be uninterested (to do pass)", muzin egin "to be unfriendly, disdainful (to do a disdain gesture)".

Not all complex predicates with egin require a bare nominal. Some of them require a locative or an adverbial ( $-\mathrm{ka}$ or $-\mathrm{z})$ :
a. Haginka egin dit
b. Hegan
egin du c. Gainez egin $d u$
tooth-Adv do Aux-DT
wing-loc
'It flied'
top-instr do Aux
'It bite me'
do Aux
'It overflew'

Finally, some of those complex predicates admit, but do not require, a structure such as the one above with a locative or adverbial complement:
a. Dantza(n) egin dute
dance-loc do Aux-T
'They danced'
b. Laster $(\mathrm{ka})$ egin dute
run-adv do Aux-T
'They ran'



b. Borroka(n) egin dute fight-loc do Aux-T 'They fought'
d. Errieta(n) egin dute dispute-loc do Aux-T 'They disputed'

\author{
c. Oihu(ka) egindute \\ scream-adv do Aux-T \\ 'They screamed,yelled' \\ e. Jauzi(ka)/salto(ka) egin dute \\ jump-adv do Aux-T \\ 'They jumped'
}

In these cases, the event denoted by the complex predicate takes on an iterative meaning: it is implied that those events happened once and again in a given time.

\subsubsection{Syntax}

These complex predicates are not instances of incorporation of the polisynthetic sort. As shown by Uribe-Etxebarria (1989), Ortiz de Urbina (1989), and (Laka,93), the bare nominal and the verb egin can be separated by a number of syntactic operations (118), and the bare nominal can take partitive Case (119) ${ }^{13}$. To this we should also add the facts above: patterns which involve postpositional complements, arguably phrasal objects $^{14}$.

\footnotetext{
${ }^{13}$ Not all complex predicates admit partitive marked bare nominals. Only those complex predicates denoting delimited events can. For instance, eztul egin "cough" and zirkin egin "move" can, as can also huts egin "to miss", tiro egin "to shoot", behaztopa egin "to stumble", birao egin "to blaspheme", salto egin "to jump", auhen egin "to lament", txalo egin "to applaud, to clap", kalte egin "to damage". Activities with no clear delimiting point do not take the partitive: light emission verbs, such as dir-dir egin "to shine", nir-nir egin "to glimmer", aspectual activities such as bultza egin "to push" , laster egin "to run", tiro egin "to shoot", hatz egin "to scratch", gogoeta egin "to think, to meditate", solas egin "to chat", buru egin "to face", gogor egin "to retaliate". Achievements do not admit partitives either: leher egin "to explode", tupust egin "to collide with", topo egin "to meet casually", bat egin "to unite", eztanda egin "to explode". The behavior of other verbs is harder to ellucidate: amets egin "to dream", lo egin "to sleep" admit the partitive, as do other mental activity verbs, such as kasu egin "to pay attention", kontu egin "to take into account" and duda egin "to doubt". Finally, what I called behavioral verbs, such as paso egin "to show indifference", planto egin "to stop (in a card game)", muzin egin "to reject", mehatxu egin "to threaten", desafio egin "to defy" do not admit a partitive nominal. Activity verbs of speaking such as hitz egin "to talk" do admit partitive objects.

14 Ortiz de Urbina (1989, p.47) provides another important argument in favor of viewing those bare nominals as true arguments: they behave as canonical arguments in causative formation. Subjects of trnaisitve verbs appear as indirect objects of causativized structures:
}

(i) a. Nik zorrak pagatu ditut

I-erg debts-abs pay-partc Aux-T

'I payed debts'

b. Niri zorrak pagaerazi dizkidate

I-dat debts-abs pay-cause Aux-DT

'They made me pay debts'

Complex predicates of the nominal+egin sort behave as transitive verbs in this regard:

(ii) a. Jonek dantza egin du Jon-erg dance do Aux-T

'Jon danced' 
(118) a. Jonek dantza egin $d u$

Jon-Erg dance do Aux-T

'Jon danced'

b. Nork egin du dantza? (wh-questions)

who do Aux-T dance

'Who danced?'

c. JONEK egin $d u$ dantza (focus movement)

Jon-Erg do Aux-T dance

'JON danced'

d. DANTZA egin du Jonek

dance do Aux-T Jon-Erg

'Jon DANCED'

e. Dantza, Jonek EGITEN du

dance Jon-Erg do-freq Aux-T

'As for dancing, Jon does dance'

(119) a. Ez du zirkinik egiten

neg Aux move-part do-prog

'He doesnt move (at all)'

b. Ez du eztulik egin

neg Aux-T cough-part do

'He didn't cough (a single time)'

\subsubsection{Simple counterparts of complex predicates}

Many of the complex predicates with egin have simplex verbal counterparts:
a. Jonek dantza egin du
Jon-Erg dance do Aux-T
'Jon danced'
b. Jonek dantzatu $\quad d u$
Jon-Erg dance-partc Aux-T
'Jon danced'

Simplex verbs can take cognate objects, complex predicates cannot:

\section{b. Joni dantza eginarazi diote Jon-dat dance do-cause Aux-DT \\ 'They made Jon dance'}

The same is not the case with simple unergatives:
(iii) a. Jonek dantzatu du Jon-erg dance-partc Aux-T
b. Jon dantzarazi dute Jon-abs dance-cause Aux-T 'They made Jon dance'
c. ?Joni dantzarazi diote Jon-dat dance-cause Aux-DT 'They made Jon dance'


a. Jonek dantza bat dantzatu $\quad d u$ Jon-Erg dance a dance-partc Aux-T 'Jon danced a dance'

b. *Jonek dantza bat dantza egin $d u$ Jon-Erg dance a dance do Aux-T 'Jon danced a dance'

There is also an aspectual difference between complex predicates and their corresponding simplex verbs that can be described in the following terms: whereas the complex predicate describes an attempted action without specifying whether the action affected the object, the simplex verb denotes an action that affects the object:

a. Zorobatek oinezko biri harrika eginzien fool one-Erg pedestrians two-Dat stone-adv do Aux-DT 'A fool threw stones at two pedestrians'

b. Zorobatek oinezko bi harrikatu zituen fool one-Erg pedestrians two-Dat shoot-partc Aux-T 'A fool stoned two pedestrians'

(123) a. Zakurrak hondakinei usna egin zien dog-Erg garbage-dat smell do Aux-DT 'The dog smelled at the garbage'

b. Zakurrak hondakinak usnatu zituen dog-Erg garbage smell-partc Aux-T

'The dog smelled (all) the garbage'

(124) a. Jonek mahaiari (*bazterrera) bultza egin zion Jon-Erg table-Dat corner-to push do Aux-DT 'Jon pushed at the table (*to the corner)'

b. Jonek mahaia bazterrera bultzatu zuen Jon-Erg table corner-to push-partc Aux 'Jon pushed the table to the corner'

Whereas in (111b) the simplex cognate verb implies that the stone throwing affected the walkers (by hurting them) in (111a) there is no implication of that sort. In (112b) the simplex verb implies a thorough examination of the garbage, whereas (112a) does not imply that. In (113b) telicity can be imposed on the simplex verb by the presence of an adlative modifier, but not on the complex predicate.

Simple verbs are almost always conjugated with a transitive auxiliary (the only exception being lehertu "to explode"), but they differ on whether they admit an overt object or not and on whether the object is a cognate object (a pure extension of the meaning of the predicate) or not. They also differ in the interpretation of ditransitive structures if they have one available. Cognate verbs can thus be divided into four classes. The first class is constituted by those verbs that take a cognate object, such as dantzatu "to dance", jolastu "to play", and borrokatu "to fight". When the verb does not have an overt object, and gives rise to a simple activity reading, it alternates freely 
between an intransitive or an intransitive auxiliary ${ }^{15}$ :
a. Jolas bat jolastu $d u$ play one play-partc Aux-T
'John played a game'
b. Jolastu $\mathrm{du}$ play-partc Aux-T 'Jon played
c. Jolastu da play-partc Aux-I
'Jon played'

The second class corresponds to the simplex equivalents of physical activity verbs such as bultza egin "to push" (bultzatu) and saka egin "to push" (sakatu) or verbs or verbal emission such as dei egin (deitu) "to call". Those verbs can be conjugated with the transitive and the ditransitive auxiliary. The choice of the ditransitive produces a non-affected reading of the sort we discussed for the complex predicate form:
a. Mikel bazterrera bultzatu du Mikel corner-to push-partc Aux-T
'He pushed Mikel to the corner'
b. Mikeli ("bazterrera)bultzatu dio
Mikel-Dat corner-to push-partc Aux-DT
'He pushed at Mikel ( ${ }^{*}$ to the corner)'

The third class comprehends a few verbs that have transitive morphology but no overt object. They correspond to aspectual activities such as dudatu "to doubt" (dudatu) or iraun "persist, to stand":
a. $\left({ }^{*}\right.$ Hori) dudatu dut
b. Iraun dut
that doubt Aux-T
stand Aux-T
'I doubted that'
'I stood'

Finally, we have the class of predicates that can take an object or not. They are aspectual activities, on which an overt object imposes a boundary:

a. Bimetro saltatu ditu

two meters jump-partc Aux-T

'he jumped two meters'

a. Bi kilometro korritu ditu

two kilometers run-partc Aux-T

'He ran two kilometers'
b. Saltatu du jump-partc Aux-T 'He jumped'

b. Korritu du run-partc Aux-T 'He ran'

There is also a group that corresponds to those verbs which necessarily take an object: laztandu (<laztan egin) "XXX", mindu (<min egin) "to hurt", birrindu (birrin-birrin egin ) "to powder", txikitu (<txiki-txiki egin) "to break into little pieces", ausiki (ausiki egin ) "to bite". Those can be considered as transitive verbs. It is further evidence for

15 Perhaps we could place in this context a dialectal distinction in the auxiliary choice of jardun "to be busy with, to spend time in", which takes an intransitive auxiliary in some western varieties and a transitive one in others 
the idea that complex predicate formation is in itself a process larger than unergative predicate formation.

\subsubsection{Other complex predicates 4.6.2.1. Noun + hartu (take)}

Other complex predicates are formed by a bare noun and the verb hartu "to take". Those are: min hartu "to get hurt (lit. to take pain)", atseden hartu "to rest (lit. to take rest", gain hartu "to dominate, to surpass", hats hartu "to breath (lit. to take breath)", hitz hartu "to compromise (lit. to take word) and kargu hartu "to reproach (to take charge)". Syntactically, they behave exactly as the complex predicates with egin:: the parts of the predicate can be separated by a number of syntactic rearrangements, such as wh-movement:

$$
\begin{aligned}
& \text { Nork hartu du min? } \\
& \text { Who-erg pain Aux-T pain } \\
& \text { 'He/she hurt him/her in two minutes }
\end{aligned}
$$

\subsubsection{Noun + eman (give)}

A last class of complex predicates is formed by a bare noun and the verb eman "to give": aurpegi eman "to face (to give face)", buru eman "to counter(to give head)", begi eman "to look at (to give eye)", amore eman "to surrender (to give surrender)", antz eman "to notice (to give look)", min eman "to hurt(to give pain)", bide eman "to cede passage (to give way)", bihotz eman "to encoureage (to give heart)", hitz eman "to promise (to give word)", musu eman "to kiss (to give face/kiss". Those complex predicates show different degrees of coalescence: while hitzeman cannot be separated, min eman for instance can be separated by all sorts of syntactic operation, as most egin predicates do. As the complex predicates with hartu, these are also incompatible with accomplishment adverbials, but most of them (leaving aside hitzeman ) are compatible with a duration adverbial. Most of these predicates (all except hitzeman and amore eman) are conjugated with the ditransitive auxiliary, differently from regular instances of eman + object, which do not require it:
a. Jonek antz eman dio/*du
b. Jonek min eman dio/*du
Jon-Erg look give Aux-DT/T

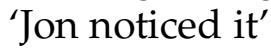

Jon-Erg pain give Aux-DT/T
'Jon hurt him'

\subsection{Psychological predicates}

If we follow auxiliary selection, we have three classes of psychological predicates in Basque. We have those predicates that select an auxiliary with Dative and absolutive agreeing morphemes (typically, Belleti\&Rizzi's piacere class), those which are invariable transitive, with absolutive-ergative agreement (corresponding to the temere or fear class of other languages), and finally, those which vary between an intransitive (absolutive agreement) and a transitive (absolutive and ergative agreement) 
auxiliary, and which we could take as equivalent to the preoccupare frighten class of other languages. The latter class is special in typological terms, since it gives rise to causative-inchoative alternations that are not possible with prototypical verbs of the preoccupare class elsewhere (Zubizarreta, 1987).

\subsubsection{Dative-Absolutive constructions}

Absolutive-Dative auxiliaries go together with verbs that typically form the piacere class in other languages. In these cases, the experiencer receives Dative Case, and surfaces as the subject of the sentence. Verbs in this class comprehend: gustatu, laketu (E) "to like", interesatu "to interest", dolutu "to repent" , damutu "to repent", bururatu, otu "to occur to, to come to mind", and gaitzitu (E) "to be offensive to". All of them except gustatu, bururatu and otu, can also select an absolutive agreeing auxiliary. In that case, the experiencer takes absolutive Case and the stimulus becomes a postpositional phrase (instrumental or locative):
a. Hori damutu/dolutu zaio
b. Horretaz damutu/dolutu da that-abs regret-partc Aux-dat-abs

a. Interesatu zaio

b. Horretan interesatu da

interest-partc Aux-dat-abs

'It interested him'

a. Laketu zaio

like-partc Aux-dat-abs

'He liked it'

\section{a. Gustatu/bururatu/otu zaio}

Aux-dat-abs

b. *Gustatu / bururatu/otu da

'He gor interested in it'

like/occur Aux-dat-abs like-partc/occur-partc Aux-I
'He liked it/it occurred to him'

\subsubsection{Purely transitive constructions (Ergative-Absolutive)}

In these constructions, the experiencer always occurs as the ergative subject, and the stimulus as the absolutive object. This class is equivalent to the temere/fear class of other languages. Verbs in this class comprehend: etsi "to desperate, to resignate",miretsi "admire", ederretsi, gurtu "to worship, to revere", gutxietsi "to despise", gaitzetsi "to condemn", onetsi "to accept", estimatu "to esteem, to appreciate", errespetatu "to respect", desiratu "to desire", irrikatu "to yearn for", ametitu/ onartu "to admit, to accept", eraman "to bear":
a. Jonek estimatzen zaitu b. Jonek eskeintza onartu du Jon-Erg appreciates Aux-T Jon-Erg offer-Abs accept Aux-T 'Jon appreciates you'
'Jon accepted the offer'

Verbs in this class differ in their aspectual configuration: whereas verbs such as errespetatu, desiratu, irrikatu, and eraman, are purely stative verbs, others such as gutxietsi, gaitzetsi, onetsi, onartu and even ederretsi, involve a judgement process and an endstate, the result or veredict of the judgement process. All of them are morphologically complex, having an adjective that marks the result of the judging 
process and a judgement verb such as etsi "consider" or hartu "take (for)":

$$
\begin{aligned}
& \text { Onetsi }<\text { on "good" + etsi "consider" } \\
& \text { Ederretsi < eder "beatiful" + etsi } \\
& \text { Gaitzetsi }<\text { gaitz "bad" + etsi } \\
& \text { Gutxietsi < gutxi "little" + etsi } \\
& \text { Onartu < on "good"+hartu "to take" }
\end{aligned}
$$

The two sets of predicates differ in their interpretation when they take a participial form. The set in (137) can receive a punctual interpretation, the others cannot:
a. Proposamena goizeko bilkuran onetsi/onartu dute proposal-abs morning-of meeting-loc accept-partc
Aux-T 'They accepted the offer in this morning's meeting'
b. Abertzale gehienek atentatua gaitzetsi dute nationalist most-erg terrorist act-abs condemn-partc Aux-T 'Most nationalists condemned the terrorist action'
c. ?Ehun urte eta gero, pintura zahar horiek ederretsi dituzte hundred year and then painting old those-abs consider beautiful Aux-T 'One hundred years later, they have considered those old pictures as beatiful'
a. *Jonek hori atzo irrikatu/desiratu zuen
Jon-erg that-abs yesterday desire-partc Aux-T
'*Jon desired that yesterday'
b. Jonek ez $d u$ hori eraman Jon-erg neg Aux-T that-abs bring 'Jon didn't bring that $/{ }^{*} J o n$ didn't bear that (yesterday)
c. Jonek ezin $d u$ hori eraman
Jon-erg cannot Aux-T that bear
'Jon cannot bear/stand that'

Some non-complex verbs such as errespetatu and adoratu, can have complex events readings, with a process part and a resultant state. With those verbs there is a clear difference in interpretation between the perfective and imperfective forms. The state readings are only possible with imperfective forms, whereas the perfective forms denote either activities or accomplishments:
a. Jon adoratzen dute han
b. Haurtxoa
adoratu
dute
Jon-abs adore-imperf Aux-T there
little child-abs worship-partc Aux-T
'They adore Jon there'
'They have worshipped the child Jesus'
'They worship Jon, there'

The complex event reading implies that the subject engages in some action that counts as the stative attitude towards the object. Consider for instance errespetatu "to respect". Again the state reading is only possible with imperfective forms, whereas the perfective form is interpreted as "showing respect": 
(141) a. Nere adiskideek errespetatzen naute

my friends-erg respect-impf Aux-T

'My friends respect me/have me respect'

b. Nere adiskideek errespetatu naute

my friends-erg respect-partc Aux-T

'My friends showed me respect'

(141b) can only be interpreted as my friends having behaved in such a way that it implied respect towards me.

\subsubsection{Transitive-Intransitive Psych-verbs (Ergative-Absolutive and Absolutive)}

This class comprehends those verbs that have a causative reading when conjugated with the transitive auxiliary, and where the stimulus is mapped as the ergative subject of the sentence. This class corresponds to the preoccupare-frighten class of other languages. They are verbs of mental change of state. Verbs in the preoccuparefrighten class can be divided into two subclasses: on the one hand, those verbs that can be conjugated with both the intransitive and the transitive auxiliary; on the other, those verbs that only admit intransitive auxiliaries. Verbs that enter into the alternating subclass are: asaldatu "to scare, to be scared, perturbed" nerbiostu/urduritu "to excite, to get (someone) nervous", harritu "to surprise, to get surprised", txunditu "to astound, to get astounded", aspertu "to bore, to get bored", kontsolatu "to comfort, console (oneself)", piztu "to hearten", alaitu "to make/become merry", poztu "to make/become joyful", zapuztu "to frustrate, get frustrated", kezkatu "to worry, to become worried", gogoratu "to remember", zoratu "to madden", haserratu "to angry, to become angry", liluratu "to dazzle", aztoratu "to confuse, get confused", nahastu "to confuse, to get messed up", ikaratu, beldurtu "to frighten, to become frightened", engainatu "to deceive (oneself)", unatu "to tire (mentally)" . All these verbs have transitive and intransitive alternates. They are verbs derived in the most part from either adjectives (urduri, nerbios "nervous", alai "merry", zoro "mad", nahas "confusion, mess") or nouns (kezka "worry", beldur, ikara "fear", lilura "dazzle", poz "joy", harri "stone"):
a. Zoratuko naute
madden Aux-T
b. Zoratu naiz
madden Aux-I
'They will madden me'
'I will become mad'
a. Beldurtu naute
frighten Aux-T
'They frightened me'
b. Beldurtu naiz
frighten Aux-I
'I became frightened'

The class that only admits intransitive auxiliaries also involves a change of mental state, although they lack any causative meaning. They represent events whose only possible origin is in the mind of the experiencer: akordatu "to remember (casually), tematu , setatu "to become stubborn" (from the nouns tema "stubbornness", and seta "obstinacy") obsesionatu "to be obsessed", lehiatu "to hurry". All of them take a postpositional complement, indicating the target or the matter of the mental event: 
(144) a. Horrekin tematu/setatu/ obsesionatu da that-with become stubborn/obsess-partc Aux-I

'He became stubborn at that/obsessed with that'

b. Horretaz oroitu/akordatu da that-instr remember Aux-I

'He remembered that'

Oroitu "to recall" can take either an intransitive or a transitive auxiliary in some western varieties.

\subsubsection{Noun + Auxiliary constructions}

Besides the verb+participle form, mental states can also be expressed through constructions that combine a noun and an auxiliary form. Depending on the mental state denoted by the noun, the auxiliary is of the ergative-absolutive form only, or alternates between an ergative-absolutive and an absolutive-dative form. Most noun+participle constructions have verb-participle counterparts. The difference between them is aspectual. Noun+auxiliary constructions are purely stative, whereas verb+participle constructions can have (depending on the aspectual mark they incorporate) all the range of aspectual meanings. Consider for an example the following pair:

a. Hura desira dut that-abs desire Aux-T 'I desire that'
* Gertatzea desira ari naiz happen-inf desire Ger Aux-I

'I keep wishing for it to happen' b. Gertatzea desira-tzen /-tu dut happen-abs desire-imperf/perf Aux-T 'I desire/have desired that it happened'

b. Gertatzea desiratzen ari naiz happen-inf desire Ger Aux-I 'I keep wishing for it to happen'

Also, the verbal form can occur without a patient argument, in generic contexts, unlike the noun plus auxiliary construction:
a. Animaliek desio dute animals-Erg desire Aux-T 'Animals desire it'

b. Animaliek desiatzen dute Animals-erg desire-gen Aux-T

'Animals desire it' $^{\prime}$

Whereas reflexivization through auxiliary selection is possible with the verbal form (at least for some speakers), the noun+auxiliary form obligatorily requires an overt reflexive phrase:

a. Jonek bere burua gorroto $d u$ Jon-erg his head hate Aux-T 'Jon hates himself' b. *Jon gorroto da Jon-abs hate Aux-I 'Jon hates himself'

b. Jon gorrotatzen da 


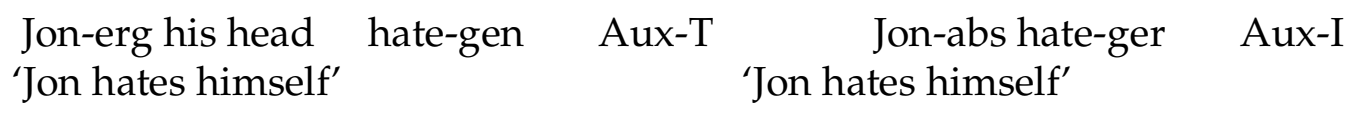

The reflexivization facts suggest that the structure of the noun+Aux construction is that of a small clause, where the absolutively marked argument is an argument of the noun, and not of the auxiliary edun "have":

(150) Xabierrek [musika hori gorroto ] du

Xabier-erg music that hate Aux-T

'Xabier hates that music'

Remember that reflexivization by intransitivizing the verb was only possible when identity of referential indexes was established between coarguments (see section 2.9). The fact that such a process is not possible with the bare nominal construction suggests that the absolutively marked argument is not an argument of have. If this is correct, then this is a raising construction, and the agreement and Case properties of the apparent object are acquired via extraction from an embedded sentential structure. Agreement (in number) is obligatory with the object:

$$
\begin{aligned}
& \text { Xabierrek barazkiak gorroto ditu } \\
& \text { Xabier-erg vegetables hate Aux-T-plural } \\
& \text { 'Xabier hates vegetables' }
\end{aligned}
$$

Nouns expressing modal notions, such as nahi "want", behar "need", asmo "intention" and gogo "wish" select for infinitival and/or participial complements (Lafitte, 1944; Artiagoitia, Ortiz de Urbina, this volume). When those nouns take a participial clause, the arguments of the participial clause agree with the matrix auxiliary (Ormazabal,1991). When the complement is a nominalized clause (the "infinitival"), then there is no agreement between the arguments of the embedded, nominalized verb and the matrix auxiliary. The participial construction provides further evidence for the idea of raising of arguments in modal periphrasis:

a. Xabierrek [barazkiak erosi] nahi ditu Xabier-erg vegetables-abs buy-partc want Aux-T-plural 'Xabier wants to buy vegetables'

b. Xabierrek [barazkiak erostea] nahi du Xabier-erg vegetables-abs buy-nom-Det want Aux-T-sing 'Xabier wants someone else to buy vegetables'

As the translations show, the choice of a participial or a nominalized clause complement has other effects besides agreement: the nominalized clause admits overt subjects, and subject reference is always disjoint. Participial clauses do not admit overt subjects, and the reference of the implicit subject is always the same as the matrix subject (Ormazabal, 1991; Artiagoitia, this volume) 
Nouns expressing mental states that are followed by an ergative-absolutive auxiliary only comprehend: maite "love", plazer "pleasure", susmo "suspicion", amets "dream", asmo "plan, purpose", desira "desire", erruki "pity", gupida "mercy", irriki "vehement desire", hastio, gorroto "hate". Also in this group are nouns expressing modality: nahi "want", behar "necessity, need" and (somewhat literary) gogo "wish", which are constructed following the noun + auxiliary pattern. The object in those cases can be either a participial or a noun phrase (the latter only nahi and behar ):
a. Hori nahi/behardut b. Hori bisitatu nahi/behardut that-abs want/need Aux-T that-abs visit-partc want/need Aux-T 'I want/need that' 'I want/need to visit that'
c. Hori bisitatu gogo $d u$ that-abs visit-partc wish Aux-T
'He wishes to visit that'

Behar actually behaves either as an auxiliary verb, with no effect on the transitivity of the verb, or as a bare noun predicate, forcing a small clause structure:
a. Egin behar $d u{ }^{*} d a$
b. Joan behar $d u / d a$
do need Aux-T/I
go need Aux-T/I
'He needs to do it'
'He needs to go'

The same alternation affects reflexivization, as one would expect. Take an inherent reflexive such as garbitu "to wash". Reflexivization via intransitivization is only possible with behar as an auxiliary, but not as a bare nominal forcing a small clause structure:

(155) a. Xabier bota behar da (reflexive)

Xabier throw must Aux-I

'Xabier must throw himself'

b. Xabierrek bota behar du (non-reflexive)

Xabier-erg throw must aux-T

'Xabier must throw something'

c. Xabierrek bere burua zubiazpian bota behar $d u / * d a$

Xabier-erg his head-abs under the bridge throw must Aux-T/I

'Xabier must throw himself under the bridge'

Nouns expressing mental states that are followed by either an ergative-absolutive auxiliary or an absolutive-dative one are: atsegin , laket "pleasure", higuin "loathing":
a. Nik hori atsegin dut
b. Hori
atsegin zait
I-erg that-abs pleasure Aux-Erg-Abs
'I like that'
that-abs pleasure Aux-Dat-Abs 'That pleases me'

In (156a), the experiencer is the ergative subject and the stimulus is the absolutive 
object. In (156b), the stimulus is the absolutive object, and the experiencer is the dative subject. The alternance is reminiscent of the difference between the temere class and the piacere class.

Nouns expressing mental states that are followed by an intransitive auxiliary only are: lotsa, ahalke "shame" and fio "trust". Their complements are respectively, genitive and instrumental (section 2.2. also, and Zabala, this volume):
a. Horren lotsa naizb. Horretaz fio naiz that-of shame Aux-I that-about trust Aux-I 'I am ashamed of that' 'I trust that'

Some oriental dialects have besides mental state nouns followed by either an intransitive or an ergative-absolutive auxiliary are: aiher "inclination" and herabe "reluctance".
a. Herabe naiz hori egitera
reluctance Aux-I that do-inf-to
'I am reluctant to do that'
b. Herabe dut hori egitera reluctance Aux-T that-abs do-inf-to 'I am reluctant to do so'

Finally, some mental state nouns are followed by egon "to be in a location" (Cf. Section 2.2): those are beldur "fear" and haserre "anger".

(159) Haserre/Beldur daude

Anger / fear are-in a location

'They are angry/fearful'

\subsection{Aspectual verbs}

Biscayan varieties of Basque have a morphologically transitive aspectual verb eroan "to carry" that contributes a frequentative meaning. It is conjugated synthetically always, and follows a participial form:

(160) a.Eman daroat

Give carry-T(erg-abs)

'I usually give it'

\section{Ditransitive Structures}

\subsection{Trivalent ditransitive}

In this group we insert all those verbs that can increase their valency with the addition of a dative marked argument realising the role of recipient or beneficiary. They all have therefore a more basic transitive bivalent use. I exclude from the group those ditransitives which encode a possession relation between the dative and some other argument of the verb (see section 6), the so-called "datives of interest". Verbs in this group are (among many others) eman "to give", erosi "to buy", saldu "to sell", esan "to tell", eskeini "to offer", erakutsi "to show", ekarri "to bring", kontatu "to tell", 
esan "to say", erantzun "to answer". They all involve a notion of transfer from an agent or causer to a recipient or beneficiary. Verbs that cannot be interpreted as involving a transfer can have ditransitive forms, but they are invariably of the possessive sort.

The dative argument is doubly marked by Case on the noun-phrase and dative affixes on the auxiliary $^{16}$ (see Hualde, 3.6.2 for important restrictions; also Albizu, 1997):
a. Jonek ardoa ekarri
$d u$
Jon-erg wine bring-partc Aux-T
b. Jonek Mireni ardoa ekarridio
Jon-erg Miren-dat wine-abs bring Aux-DT
'Jon brought wine for Miren'

\subsection{Bivalent ditransitive verbs}

A few verbs in Basque require ditransitive auxiliaries while showing only two arguments. They are eritzi "to think, have an opinion about" (see section 7), eutsi "to retain, to hold on", and the aspectual verbs eman "to give", ekin "to engage in" and eragon "to keep on, hold on to". Among the aspectual verbs the last two take noun phrase or nominalized clausal complements, the first only noun phrases with an eventive meaning:
a. Lanari ekin dio work-dat engage-in Aux-DT 'He began to work, he engaged in working'
b. Eragon beti gauzaonen bati (S.) hold-on always thing good-g one-dat 'Hold on to some good thing always'
c. Emaztea hil eta gero, negarrari eman zion wife-abs die and after, cry-D-dat give Aux-DT
'After his wife died, he cried very often (gave himself to crying)'

None of this verbs admits any overt absolutive argument.

\subsection{Alternating Verbs}

A few bivalent verbs alternate between a transitive and a ditransitive auxiliary: deitu "to call", lagundu "to help", bultzatu "to push", jarraitu "to follow" , begiratu "to look at", barkatu "to pardon", eraso "to attack", esetsi "to attack", itxaron "to wait", abisatu "to notify", erreparatu (W) "to pay attention", utzi "to allow". Among them we shall draw two groups: first, those verbs where both the transitive and the ditransitive form accompany an (apparently) bivalent verb. In this group we have deitu, abisatu ,

16 In some eastern varieties, the dative agreement is optional (Lafon, 1961):

(i) Eman du haurrari

Give Aux-T child-dat

'He gave it to the child' 
bultzatu, esetsi and lagundu.
a. Xabier deitu dute
b. Xabierri deitu diote
Xabier-abs call-partc Aux-T
Xabier-dat call-partc Aux-DT
'They called Xabier'
'They called Xabier'

Although the two forms seem to be equivalent at first glance, there are important aspectual differences that show up when we add modifiers. If we add an adlative modifier to (1a) and (b), we get different interpretations (also with abisatu ):

(164) a. Xabier bulegora deitu dute

Xabier-abs office-ad call-partc Aux-T

'They called Xabier to the office'

b. Xabierri bulegora deitu diote

Xabier-dat office-adl call-partc Aux-DT

'They called Xabier to the office'

Whereas (164a) is ambiguous between a reading in which Xabier is in his office and they called him there, and a reading where Xabier is called from an office and ends there, $(164 b)$ has only the first reading. The structure of (164a) is rich enough to allow different scope positions for the adlative modifier. (164b) is in this regard identical to its complex predicate alternate dei egin "to do call", that behaves as the ditransitive form.

Similarly with bultzatu "to push":
a. Autobuserabultzatu gaituzte bus-adl push-partc Aux-T
'They pushed us into the bus'
b. Autobusean/? Autobusera bultzatu digute
bus-loc/adl
'They pushed us in the bus'
c. ?Autobusera bultza egin digute
bus-adl push do Aux-DT
'They pushed us into the bus'

\section{push-partc Aux-DT}

In the case of lagundu "to help, to accompany", the transitive form is more accurately translated as "to help", whereas the ditransitive form is ambiguous between accompany and help:

a. Ezezagun batzuek lagundu gaituzte unknown some-erg help-partc Aux-T 'Unknown people helped us'

b. Ezezagun batzuek lagundu digute unknown some-erg help/accompany-partc Aux-DT 'Unknown people helped/accompanied us' 
The second group comprehends those alternating verbs such that their ditransitive alternates always follow bivalent predicates, whereas their transitive forms are monovalent: in this group are itxaron "to wait", begiratu "to look", eraso "to attack", erregutu "to supplicate", erreparatu "to pay attention". In their transitive form, these verbs are unergative:
a. Jonek itxaron $d u$ Jon-erg wait Aux-T 'Jon waited'
b. Jonek itxaron dit Jon-erg wait Aux-DT 'Jon waited for me'
b. Begiratu dut look-partc Aux-T 'I looked'
b. Joni begiratu diot Jon-dat look-partc Aux-DT 'I looked at Jon'

\section{Possessive constructions}

\subsection{Attributive}

\subsubsection{Individual level attributions}

Many languages have the ability to encode possession relations not only through specific verbs or noun phrase morphology, but also directly in the argument structure of the verb. The finite morphology of the verb or the auxiliary then expresses the addition of a possessor. We can illustrate the alternance between noun phrase internal and noun phrase external possession with the following constrast in Basque:
a. Bere anaia da
his brother Aux-I
b. (??Bere) anaia $d u$
'It is/He is his brother'
his brother Aux-T
'He is his brother (lit. he has him brother)'

The structure of (168b) involves a predication relation between the possessed term and the term expressing the kind of possession relation: they both optionally agree in number. The auxiliary, on the other hand, agrees in person and number with both the subject possessor and the possessed:

$$
\begin{aligned}
& \text { Nik alproja horiek adiskide(ak) ditut } \\
& \text { I-erg cur those-abs friend(s) Aux-T } \\
& \text { 'Those curs are my friends' }
\end{aligned}
$$

The two alternates have slightly different interpretations though, as we can see from the glosses. Whereas (168a) admits an interpretation where the subject is not referential, $(168 b)$ doesn't:
Nork deitzen $d u$ ?
Beren anaia da / ??Anaia dute who call-ger Aux-T their brother Aux-I/ brother Aux-T 'Who's calling? It is their brother/??He is their brother'

Noun phrase internal possessions typically express a wider range of relations than 
noun external ones. In order for the noun phrase external transitive possession to be admissible, it must be either of the inalienable kind or pertaining to something like the "personal sphere". The personal sphere includes, besides affective notions such as friend or family (171), professional relations (172), and familiar objects (173). Part/whole relations are also accessible through this construction (174). Possessive relations that fail to express any of those relations are inadmissible in a external possession structure (175)-(176):

a. Jonen anaia da Jon-G brother is 'He/it is Jon's brother'

(172) a. Kotxeak Jonen lanbidea dira cars-abs Jon-G occupation Aux-I 'Cars are Jon's occupation'

(173) a. Hori nere ohea da that-abs my bed Aux-I 'That is my bed' b. (Hango hura) Jonek anaia $d u$ that one-abs Jon-erg brother has 'That one is Jon's brother'

b. Jonek kotxeak lanbide ditu Jon-erg cars-abs occupation Aux-T 'Cars are Jon's occupation' b. Hori ohea dut that-abs bed-D aux-T

'That is my bed'

(174) a. Gela hori etxearen ganbara da room that-abs house-G loft Aux-I

'That room is the loft of the house'

b. Etxeak gelahori ganbaradu

House-erg room that-abs loft Aux-T

'That room is the loft of the house'

a. (Hango hura) Eusko Jaurlaritzaren bozeramailea da that one-abs Basque Government-G spokesman/woman-abs is

'That one is the spokesman/woman of the Basque Government'

b. *(Hango hura ) Eusko Jaurlaritzak bozeramaile du that one-abs Basque Government-erg spokesman/woman has 'That one is the spokesman/woman of the government'
a. Hori nere liburua da
b. ${ }^{*}$ Hori liburua dut
that-abs my book-D Aux-I
that book-D Aux-T
'That is my book'
'That is my book'

Not all possessive relations expressed trhough a transitive structure exclude an overt possessive. In this there seems to be a difference between purely inalienable relations (177), on the one hand, and professional relations (178) and familiar objects on the other (179):

a. Hori nere anaia da that-abs my brother Aux-I 'That is my brother' b. Hori (??nere) anaia dut that-abs my brother Aux-T

'That is my brother (lit. I have that (as) brother)

b. Hori (nere) lanbidea dut that (my) job-D Aux-T 'That is my job' 

a. Hori nere ohea da
b. Hori (nere) ohea dut
that-abs my bed-D Aux-I
'That is my bed'
that-abs my bed Aux-T
'That is my bed'

Inalienable possession and other types of possession that enter into this type of construction also differ in the entailments they give rise to, despite their (apparent) formal identity:
a. Jonek Aitor anaia $d u$ Jon-erg Aitor-abs brother Aux-T
'Aitor is Jon's brother'
b. Jonek kotxeak lanbide ditu
Jon-erg cars-abs job Aux-T
'Cars are Jon's occupation'

Whereas from (180a) it follows that Jon must have a brother, it does not follow from (180b) that Jon must own any car.

\subsubsection{Stage level attributions}

Possessive relations involving a temporary or transient condition can also be expressed either through a noun-phrase internal relation or through a noun phrase external relation. The transitive, noun external, structure does not admit an overt possessor when the possession relation is of the inalienable kind (181). Otherwise it is optional (182):

(181) a. Nere eskuak ikara/bero daude

my hands-abs trembling/hot are-in a location

'My hands are trembling'

b. $\left({ }^{*}\right.$ Nere $)$ eskuak ikara/bero ditut

I-erg my hands-abs trembling/hot Aux-T(pl)

'I have my hands trembling'
a. Nere ohea bero dago
b. Nik (nere) ohea bero dut
my bed-abs warm is-in a location I-erg my bed-abs warm Aux-T
'My bed is warm'
'I have my bed warm'

\subsection{Lexical verbs}

The possessive forms can also be extended to intransitive and transitive lexical verbs. Consider for instance the following alternation:
a. Bere ama
hil da
his mother-abs die Aux-I
'His mother died'
b. Ama hil zaio mother-abs die Aux-dat-abs 'His mother died (on him)'

Motion verbs give rise to an interesting ambiguity when they occur in the dativeabsolutive form. Consider the following cases: 
b. Irakaslea joan zaio

teacher-abs go Aux-dat-abs

'The teacher went to him'

'His teacher left'

The dative argument can represent either a hidden possessor or a patient (a true argument of the verb). In the first case, the verb behaves as its intransitive form, where the absolutive constituent is the only argument of the verb and marks the patient, in the case of iritsi, or the theme (object in motion) in the case of joan. In the second case, the dative only marks a possessive-like relation with the absolutive ${ }^{17}$.

Verbs of inherently specified motion (such as igo "to climb", jaitsi "to go dawm, to descend" or igaro "to cross" give rise to two sorts of transitive structures: on the one hand, transitive structures in which the object is a Theme (185a); on the other, affected transitive structures in which the object is some sort of measure (185b):
a. Jonek patata zakuak jaitsi ditu
Jon-erg potato sacks-abs take down Aux-T
'Jon took down the potato sacks'
b. Jonek 50 metro jaitsi ditu urpean

Jon-erg 50 meters descend-partc Aux-T underwater 'Jon descended 50 meters'

Possessive ditransitive constructions can only be construed from (186a), but not from (186b):
a. Jonek patatak jaitsi dizkit
Jon-erg potatoes-abs take down Aux-DT
'Jon took down my potatoes/Jon took down the potatoes on my interest'
b. *Jonek 50 metro jaitsi dizkit urpean
Jon-erg 50 meters descend-partc Aux-DT underwater

\footnotetext{
${ }^{17}$ Other modifiers may disambiguate between the two meanings. For instance, an ablative or locative postpositional phrase makes (2a) inequivocally non-possessive (but not (2b)):
}

(i)

$$
\begin{aligned}
& \text { Eskutitza Madriletik/-n iritsi zitzaion } \\
& \text { letter-abs Madrid-abl/loc arrive-partc Aux-I-dat-abs (past) } \\
& \text { 'The letter got to him from/in Madrid' }
\end{aligned}
$$

Interestingly, adlative modifiers (and all those that are constructed from it) are compatible with both the possessive and the directional interpretations, in both (2a) and (2b):

(ii) Eskutitza Madrilera iritsi zaio

letter-abs Madrid-adl arrive Aux-I-dat-abs

'The letter got to him to Madrid (to his address in madrid)'

'His letter arrived to Madrid' 
'Jon descended 50 meters underwater on my interest'

Transitive verbs may also encode possession in the argument structure of the verb. In that case, the auxiliary becomes ditransitive. Consider for instance hautsi "to break":
a. Mikelek Jonen kotxea hautsi du mikel-erg Jon-g car-abs break-partc Aux-T
'Mikel broke Jon's car'
b. Mikelek Joni (bere) kotxea hautsi dio Mikel-erg Jon-dat his car break-partc Aux-DT 'Mikel broke his car to Jon'

If the possession relation is of the inalienable sort, the noun phrase internal possessor must disappear:

(188) a. Mikelek Jonen sudurra hautsi du Mikel-erg Jon-g nose-abs break Aux-T

'Mikel broke Jon's nose'

b. Mikelek Joni (*bere) sudurra hautsi dio

Mikel-erg Jon-dat his nose-abs break-partc Aux-DT

'Mikel broke Jon his nose'

The ban on the overt presence of the possessive in inalienable constructions dissappears if the possessed element is one in a set of identical elements:

(189) a. Mikelek Jonen beso bat hautsi du

Mikel-erg Jon-g arm one-abs break Aux-T

'Mikel broke one of Jon's arms'

b. Mikelek Joni bere beso(etako)bathautsi dio

Mikel-erg Jon-dat his arm(loc-g) one break Aux-DT

'Mikel broke Jon one of his arms'

There is a difference in meaning between the noun phrase internal possessive construction and the noun phrase external one in the case of inalienable possession. The noun phrase external construction implies that the dative-marked element and the absolutive-marked element enjoy material integrity (form a unit). Consider the contrast below:
a. San Vicenteren besoa hautsidute
Saint Vincent-g arm-abs break Aux-T
'They broke Saint Vincent's arm'
b. San Vicenteri besoa hautsidiote
Saint Vincent-dat arm-abs break Aux-DT
'They broke Saint Vincent's arm' 
Whereas in (b) it is necessary that Saint Vincent has an arm as part of his material integrity which results broken as a result of pagan or heretic violence, in (a) this is not necessary: it could be for instance the relic in the cathedral of Valencia, involuntarily broken by some unattentive tourist. Family relations also give rise to an equivalent contrast:
a. Jonen ama
hil da
Jon-g mother-abs die Aux-I
'Jon's mother died'
b. Joni ama hil zaio
Jon-dat mother die Aux-dat-abs
'Jon's mother died'

Whereas to utter (191b), Jon must be directly affected (and therefore alive) when his mother dies, this is not necessary to utter (191a). (191a) can be uttered in a situation in which Jon is dead a longtime ago, and now his mother dies.

In very colloquial (and stigmatized) registers of western Basque, inalienable reflexive relations can be expressed either by noun-phrase internal possession or by reflexivizing (ditransitivizing) the auxiliary:

a. Mikelek besoa hautsidu

Mikel-erg arm-abs break Aux-T

'Mikel broke his arm'

b. Mikel besoa hautsi da

Mikel-abs arm-abs break-partc Aux-I

'Mikel broke his arm'

There is a difference between the two: only the former, transitive, form admits agentive modifiers (181).

(193) a. Mikelek besoa nahita hautsi $d u$

Mikel-erg arm-abs voluntarily break-partc Aux-T

'Mikel broke his arm voluntarily'

b. ??Mikel besoa nahita hautsida

Mikel-abs arm-abs voluntarily break Aux-I

'Mikel broke his arm voluntarily'

Surprisingly enough, these intransitive forms admit plurals in a very restricted way and when so, with marginal results:
a. *Adiskideak besoak hautsidira
friends-abs arms-abs break Aux-I
'My friends broke their arms'
b. ?Adiskideak besoa hautsi dira
friends-abs arm-abs break Aux-I(plural)
'My friends broke (each) an arm'
c. *Adiskidea besoak hautsi da/dira 
friend-abs arms-abs break Aux-I(sing/plural)

'My friend broke his arms'

\section{Verbs of saying, thinking and judging}

\subsection{Intransitive}

Some factive verbs (verbs of thinking whose finite complement is understood factively) are conjugated with the intransitive auxiliary in Basque: akordatu "to remember", jabetu "to come to realize", ohartu "to realize". Two others admit both a transitive and an intransitive auxiliary: gogoratu, gomutatu "to recall". The finite complement of intransitive auxiliaries is probably not a canonical object. Two pieces of evidence can be brought up in favor of this view: (i) DP objects of those verbs are never absolutive, but postpositional (ii) Basque has a general ban on relativizing certain postpositional non argumental elements (Artiagoitia,1992), and relativizing the finite complement or a de dicto demonstrative is impossible with intransitive verbs of saying, thinking and judging. Verbs such as gogoratu "to recall", that have both transitive and intransitive alternates are significant in this regard. In the transitive case the complement is absolutive and admits relativization, but not in the intransitive one:
a. Horretaz gogoratu naiz that-instr recall-partc Aux-I
b. Hori gogoratu dut 'I recalled that' that-abs recall-partc Aux-T
'I recalled that'
a. ${ }^{*}$ Gogoratu naizena hori/horretaz $d a$ recall-partc Aux-I-rel-D that-abs/instr Aux-I 'What I recall is that'
b. Gogoratu dudana hori da recall-partc Aux-T-rel-D that-abs Aux-I 'What I recall is that'

A verb of speech, mintzatu "to talk", is intransitive, and conjugated with the auxiliary izan "to be":

\section{Horretaz mintzatu naiz \\ That-about talk-partc Aux-I \\ 'I talked about that'}

Finally, the verb egon "to be in a location" can be used as a verb of judgement, with the meaning of "to be in the opinion that":

$$
\text { Nago ez direla garaiz etorriko }
$$

Am-in a location neg Aux-I-Comp in time come-fut

'I think (am in the opinion) that they will not be on time'

This verb cannot be negated:
${ }^{*} E z$ nago
etorriko dir-ela/-enik 
neg am-in a location come-fut Aux-I-Comp

'I don't think that they will come'

\subsection{Transitive verbs}

Most of the verbs of saying, thinking and judging are transitive. Among them aditu "to hear, to understand, to perceive", adierazi "to express, to let someone know", adostu "to agree on something", agertu, azaldu "to explain", agindu "to promise, to order", aholkatu "to advise", aipatu "to mention", salatu "to denounce", sortu , zabaldu "to invent, spread the false idea that", amestu "to dream", asmatu "to invent", aurreratu "to anticipate that", iragarri "to announce", hitzeman "to promise", dudatu/duda egin "to doubt", deklaratu "to declare", aldarrikatu "to proclaim", entzun "to hear", erabaki "to decide", esan "to say", erakutsi "to show", erantzun "to answer", eskatu "to ask for", galdetu "to ask", berretsi "to confirm", hotsegin "to call (saying that)", idatzi "to write", leitu, irakurri "to read", ihardetsi "to reply", ikasi "to learn", jakin "to know", kontatu "to tell", xuxurlatu "to whisper", oihu egin "to shout (that)", igarri "to guess, to divine", pentsatu "to think", sinetsi "to believe", uste edun "to believe (have an oppinion)" and ukatu "to deny". Among the transitive verbs of saying, thinking and judging, there are some that have been adapted to such functions from apparently more basic meanings: egin "to do", eman "to give", jo "to hit". The first (egin) is used for conjectures (200), the second (eman ) to denote hypothetical events (201):

a. Egingo nuke Xabier taberna horretan dagoela

Do-fut hyp-T Xabier-abs pub that-in is-in a location-Comp

'I would say that Xabier is in that pub'

b. Egin nuen nere arterako lan hura ez zela komeni

do Aux-T my own-for work that-abs neg was-Comp convenient

'I said to myself that that work wasn't convenient'

(201) a. Emango nuke uzta ederra izango dugula

give-fut Aux-T-hyp good be-fut Aux-T-Comp

'I would say that we will have a good harvest'

b. ??Eman nuen ez zela etorriko

give Aux-T neg Aux-I-Comp come-fut

'I conjectured that he would not come'

Jo "to hit" is used as an equivalent of "take for" when the complement is prolative:

(202) Tontotzat jo dute

Dumb-pro hit Aux-T

'They considered him as dumb'

Raising verbs of saying, thinking and judging are morphologically transitive: iduri "to seem" and eman "to seem":

(203) a. Iduridu Jon haserre dagoela seem Aux-T Jon-abs angry be-in a location-Comp 
'It seems that Jon is angry'

b. Jonek iduri du haserre dagoela

Jon-erg seem Aux-T angry be in a location-Comp

'Jon seems to be angry (lit. Jon seems that is angry)'

The embedded subject of (a) is raised in (b), and takes ergative Case. Evidence for raising is provided by the fact that no overt element can occur as the subject of the embedded clause when there is an overt subject in the matrix (but see Artiagoitia, section, this volume):

(204) *Jonek iduri $d u$ bere taldeak galdu duela

Jon-erg seem Aux-T his team-erg lose-partc Aux-T-Comp

'* Jon seems that his team lost'

Similarly for eman. When iduri/irudi takes an aspectual mark, it is automatically conjugated with the dative-absolutive auxiliary. The result is a non-raising verb that can have two different overt subjects in the matrix and the embedded clause, respectively:

(205) Joni iruditu/tzen zaio Xabier ez dela etorriko Jon-dat seem-partc/ger Aux-I (dat-abs) neg Aux-I-Comp come-fut 'It seems to Jon that Xabier will not come ((lit.) To Jon seems that...)'

Raising of the absolutive embedded subject is not possible (with flat, non-focus intonation):

(206) *Nonbait, Xabier Joni irudituzaio ez dela joango Apparently, Xabier-abs Jon-dat seem Aux-I(dat.abs) neg Aux-I-Comp go-fut "Apparently, Xabier seems to Jon that (Xabier) will not come'

\subsection{Ditransitive verbs}

There are two morphologically ditransitive verbs of saying and judging in Basque. One is eritzi "to judge", that has both synthetic and periphrastic forms and the other one, which can only be conjugated synthetically is *io "to say". Part of the latter's defective paradigm is formally identical to some forms of the ditransitive auxiliary. Consider for instance (207), where the bivalent forms of *io are compared to the ditransitive auxiliary:
a. Ekarri diot =I something to him 'bring' diozu =you something to him dio =He something to him $\operatorname{diog} \mathrm{u}=$ We something to him diozue $=$ You something to him diote =They something to him

\author{
b. diot =I say \\ diozu=you say \\ dio=he says \\ diogu=we say \\ diozue $=$ You say \\ diote=they say
}


To the ditransitive auxiliary following a verb like bring, corresponds a formally identical synthetic verb with a transitive meaning of "someone saying something". There are no such forms involving anything other than third person absolutives and datives. The verb *io has also ditransitive forms, but those include a further dative marker -ts- and a person affix referring to the dative argument:

(208) a. Jonek Xabier etorriko dela dio

Jon-erg Xabier-abs come-fut Aux-I-Comp he-says

'Jon says that Xabier will come'

b. Jonek etorriko dela diosku $(<$ dio + ts $+g u)$

Jon-erg come-fut Aux-I-Comp he tells us (say+ditransitive $+1^{\text {st }} \cdot \mathrm{pl}$ )

'Jon tells us that Xabier will come'

The verb eritzi "to judge" is also conjugated as a ditransitive verb, although it takes no overt absolutive argument:

(209) Nik horri interesgarrideritzot

I-erg that-dat interesting judge(dat-abs-erg)

'I judge that as interesting' 


\section{References}

Sources of examples:

Aresti, G. (1983) [1968] Harri eta Herri , Harria liburuak-1, Haranburu editor, Donostia.

Ibiñagabeitia, Andima (1999) [1950-1967] Idazlan Hautatuak, edited by Pako Sudupe, Elkarlanean, Donostia.

Michelena, Luis (1987-1998) Orotariko Euskal Hiztegia-Diccionario General Vasco , Euskaltzaindia, Desclee de Brouwer-Ediciones Mensajero, Bilbao.

Sarasola, I (1996) Euskal Hiztegia , Kutxa Fundazioa, Donostia.

Bibliography:

Artiagoitia, X. (1992) "Why Basque doesn't relativize everything". In Syntactic Theory and. Basque Syntax, edited by J. Lakarra and J. Ortiz de Urbina. Supplement 27 of the Anuario de Filologia Vasca Julio de Urquijo. Diputación Foral de Gipuzkoa, Donostia. 11-37.

Albizu, P (1997) "Generalized Person-Case Constraint: A Case for a Syntax-Driven Inflectional Morphology" . In Theoretical Issues at the Morphology-Syntax Interface, edited by A. Mendikoetxea and M. Uribe-Etxebarria. Supplement 40 of the Anuario del Seminario Julio de Urquijo. Diputacion Foral de Gipuzkoa , Donostia. 1-35.

Burzio, L. (1981) Intransitive Verbs and Italian Auxiliaries . Doctoral Dissertation, MIT, Cambridge, Massachusetts.

De Rijk (197X)

Dowty, D.R. (1979) Word Meaning and Montague Grammar . Reidel, Dordrecht. 
Dixon, R.M.W. (1994) Ergativity . Cambridge Studies in Linguistics 69, Cambridge University Press.

Fernandez, B. (1997) Egiturazko kasuaren erkaketa euskaraz . EHUko argitalpen zerbitzuaPublication Services of the University of the Basque Country.

Grimshaw, J. (1990) Argument Structure . Linguistic Inquiry Monograph 18, MIT Press, Cambridge, Massachusetts.

Hale, K. and S.J Keyser (1993) “On Argument Structure and the Lexical Expression of Syntactic Relations" . In The View from Building 20: Essays in Honor of Sylvain Bromberger , ed. By K. Hale and S.J. Keyser, Current Studies in Linguistics 24, MIT Press.

Heath, J. (1972) "Genitivization in complement clauses." In Anuario del Seminario de Filologia Vasca Julio de Urquijo , 6, 46-66. Donostia.

Jackendoff, R (1983) Semantics and Cognition . Current Studies in Linguistics Series 8. MIT Press.

Laka, I. (1993) "Unergatives that assign ergative, unaccusatives that assign accusative2 in MIT Working Papers in Linguistics 18: Papers on Case and Agreement 1 , 149-72. Department of Linguistics and Philosophy, MIT, Cambridge, Massachusetts.

Levin, B. (1983) On the Nature of Ergativity . Doctoral dissertation, MIT, Cambridge, Massachusetts.

Levin, B. (1993) English Verb Classes and Alternations . The University of Chicago Press.

Levin, B. and M. Rapaport (1995) Unaccusativity . Linguistic Inquiry Monographs 26, MIT Press,

Lyell, J. (1997) Aspects of Ergativity . Doctoral dissertation, University of Washington.

Ormazabal, J. (1991) "Modal Verbs in Basque and Head-Movement." In Memoriae L. Mitxelena Magistri Sacrum. Pars Altera . Edited by J. Lakarra and I. Ruiz Arzalluz. Separata 14 of the Seminario de Filologia Vasca "Julio de Urquijo". Donostia. 835-845.

Ortiz de Urbina, J. (1989) Parameters in the Grammar of Basque . Foris, Dordrecht.

Perlmutter, D.M. (1978) "Impersonal Passives and the Unaccusative Hypothesis". In Proceedings of the Fourth Annual Meeting of the Berkeley Linguistics Society, 157-89. Berkeley Linguistics Society, University of California, Berkeley.

Pustejovsky, J (1995) The Generative Lexicon . MIT Press. 
Oihartzabal, B. (1994) "Contribution de la comparaison typologique à une analyse des rapports ergativité-(in)transitivité en Basque." In Jean Baptiste Orpustan (ed.) La langue basque parmi les autres-Actes du colloque de l'URA 1055 du CNRS . Editions Izpegi.

Rebuschi, G. (1982) Structure de l'énoncé en Basque . L'Europe de la tradition orale 3, Société d' études linguistiques et anthropologiques de France, Paris.

Tenny, C. (1994) Aspectual Roles and the Syntax-Semantics Interface, Studies in Linguistics and Philosophy 52, Kluwer Academic Publishers.

Uribe-Etxebarria, M. (1989)

Van Valin, R (1990) "Semantic parameters of split intransitivity." In Language 22, 221260.

Zabala, I. (1993) Predikazioaren teoriak gramatika sortzailean (Euskararen kasua). Doctoral disseratation, University of the Basque Country, Vitoria-Gasteiz.

Zubizarreta, M.L. (1987) Levels of Representation in the Lexicon and in the Syntax . Foris, Dordrecht. 
